\title{
PRÁCTICAS JUdiciales, TRANSFormación SOcial Y acción POLfTICA EN CATALUÑa (SIgLOS IX-XIII)
}

por

\author{
JOSEP M." SAIRACH \\ Universidad Pompeu Fabra (Barcelona)
}

RESUMEN: Con documentos procedentes del Cartulario de Sant Cugat del Vallés y del Cartulario de la sede de Gerona (llamado de Carlomagno) se estudian los mecanismos de resolución de conflictos en Cataluña en los siglos $I X-X I H$. La atención se centra en la evolución de la administración de justicia a fin de señalar los cambios más significativos. La investigación ha permitido distinguir cinco fases: 1) Los siglos $I X y \mathrm{X}$, en que estuvo vigente la tradición hispanogoda basada en el derecho escrito y el cumplimiento, muy escrupuloso, de las normas procesales de la Lex Visigothorum: 2) la primera mitad del siglo $\mathrm{XI}$, caracterizada por la continuidad y desgaste de esta tradición, que empieza a ser rechazada por los poderosos; 3) La segunda mitad del siglo XI y la primera del XII, en que la justicia ordinaria (en particular el tribunal condal) desaparece sustituida por pactos, acuerdos y arbitrajes; 4) La segunda mitad del siglo XII en que estas prácticas extrajudiciales conviven con la aparición de procesos presididos por expertos en derecho romano y feudal, en coincidencia con el retomo de la justicia condal o real, y 5) el siglo XII caracterizado por la cristalización del derecho escrito, la pluralidad jurisdiccional, la profesionalidad de los juristas, la regularización de los procesos según las normas romanocanónicas y la importancia del derecho romano, junto a las costumbres escritas y las compilaciones de derecho feudal. Estos cambios se ponen en relación con la evolución social y politica: primero, con la desaparición de los últimos residuos de una concepción pública del poder, basada en una cierta noción de derechos y deberes colectivos, $y$, después, con la creación del Estado feudal. El autor, que efectua su análisis institucional de la justicia desde la perspectiva de la lucha de clases, toma para ello como referencia los conflictos entre poderosos y entre éstos y las clases inferiores. En sus conclusiones piensa que la desaparicion temporal de los procesos regulares y de la confianza en el derecho escrito, en provecho de un sistema de pactos (siglos $\mathrm{XI}-\mathrm{XII}$ ), condujo a formas más personales, arbitrarias y opresivas de explotación social. Sin olvidar, por tanto, el contenido de clase de la justicia tradicional hispanogoda (siglos $I X-X$ ) y de la justicia feudal institucionalizada (siglo XIII), concluye que para las clases trabajadoras siempre ha sido mejor el precepto legal que el arbitrio señorial. 
Palabras clave, Edad Media. Cataluña. Justicia. Poder. Acción política. Cambio social y juridico.

ABSTRACT: Using documents from the Sant Cugat del Valles and Girona archives, this paper analyzes the conflict resolution mechanisms in Catalonia between the 9 th and 13th century. Focusing on the evolution of the administration of justice I point out the most meaningful changes in this period. We can differentiate five periods: 1) between the 9 th and 10th century characterized by the Lex Visigothorum; 2) the first half of the 11th century characterized by the continuity and erosion of this tradition; 3) between the late 11th and the early 12th century when the ordinary justice disappeared being substituted by agreements and arbitration; 4) the second half of the 12th century when the practices of the previous period coincide with the emergence of legal processes leaded by experts on roman and feudal law; and finally 5) the 13th century characterized by the rise of the written law, the jurisdictional plurality, the creation of professional jurists, the of the regularized processes according to the "roman canonicn rules, and the importance of roman Law, with the written customs, and the consolidation of feudal law. All these changes are related to the social and political evolution: first, by disappearance of the latest vestiges of a public conception of power based on a notion of collective rights and duties, and with the creation of a feudal state. Using a class struggle point of view, I analyze the institutional conflicts among the powerful and also betwwen the powerful and the lower classes, I conclude that the gradual disappearance of the regular processes and the distrust on written law, favored an informal system which in tum lead to more personal and oppressive mechanisms of social explotation. Althought I do not ignore the class content of the "hispano.godas traditional justice (9th to 10th century) and also of the feudal institutionalized justice (13th century) I argue that for the working classes the legal precept was always better that the manorial arbitration.

KaY worbs: Middle Ages. Catalogne. Law. Justice. Power. Judical practices. Polltical action. Legal change. Soclal change.

¿Cómo se administró justicia en los siglos DX-XIit? ¿Qué cambios se observan en la mecánica del pleito en esta época? ¿Como pueden interpretarse, desde el punto de vista de la evolución social y del poder, las variaciones detectadas? Son las preguntas que han guiado nuestra investigación.

\section{FUENTES Y MÉTODO}

Hemos trabajado con fuentes diversas, pero sobre todo con los documentos del cartulario de la abadía de Sant Cugat, en el Vallés (contiene 1.391 documentos) ', y con los del cartulario de la catedral de Gerona, llamado de

1 RuUs SERra, José (ed.), Cartulario de "Sant Cugat" del Vallés, 3 vols., Barcelona, 1945-1947. En adelante CSCV seguido del número del documento.

Hispania, LVIJ/3, nùm. 197 (1997) 1009-1048 
Carlomagno (contiene 625 documentos) ${ }^{2}$. Del cartulario de Sant Cugat hemos seleccionado para nuestro propósito 155 escrituras. Del cartulario de Carlomagno 99. Además de fuentes singulares, utilizadas como elementos de apoyo, el núcleo de esta investigación se ha construido, pues, con 254 documentos: 13 del siglo IX, 8 del X, 40 del XI, 144 del xI y 49 del XIII. La muestra da una visión muy parcial de los conflictos y procesos, puesto que casi únicamente se refieren a disputas en el marco de la gran propiedad o entre poderosos.

En cuanto al método, nos centramos en el análisis y descripción de la documentación seleccionada, que agrupamos por las secuencias cronologicas que la investigación nos ha permitido establecer. Se trata de actas de juicios, pruebas testificales, sentencias, arbitrajes, concordias y actas de renuncia o de reconocimiento del derecho que asiste a la parte contraria en las disputas (definitiones, exvacuationes).

Paralelamente al examen de la documentación, interpretamos las continuidades y cambios observados en el contexto general de la evolución social y política del periodo, y en relación con las aportaciones de la historiografía.

\section{LA TRADICIÓN HISPANOGODA}

Los documentos de los siglos $\mathrm{x}$ y $\mathrm{x}$ mayoritariamente son actas de juicios. Los tribunales, figuran en el encabezamiento de los documentos, introducidos con la expresión in presentia de o in iuditio de, seguida del nombre de sus miembros, a los que a veces acompañan expresiones genéricas del tipo de los que in ipso placito residebant o de los que sedebant in mallo publico ${ }^{3}$. Por orden de mención, puede distinguirse, al menos convencionalmente, una presidencia, unos jueces en sentido estricto (a veces un auténtico colegio de jueces), un grupo heterogéneo de hombres selectos (boni homines) y un sayón. En la presidencia encontramos a condes, obispos, abades y vizcondes, a veces aisladamente 4 , a veces emparejados y a veces flanqueados de fieles (vassos dominicos). La combinación conde-obispo ${ }^{5}$ o obispo-abad ${ }^{6}$ es frecuente, aunque también puede encontrarse a dos vizcondes al frente de un tribunal o un obispo emparejado a un vizconde ${ }^{\text {? }}$.

\footnotetext{
2 MARQuÈs, Josep Maria (ed.), Cartoral dit de Carlemany, del bisbe de Girona (siglo $(x-x / \mathrm{V}), 2$ vols., Barcelona, 1993. En adelante $\mathrm{CC}$ seguido del número del documento.

${ }^{3} \mathrm{CC} 3,5$ y 8.

4 Condes y condesas solos o acompafíados de cónyuges y descendientes en CC 59 y 78 , y CSCV $437,438,439,452,464,470,479,496,542,545,612$ y 613 . Obispos solos en CC $1,4,14$, $15,16,17,18,22$ y 23, y CSCV 512 . Estas referencias incluyen documentos de los primeros decenios del siglo $\mathrm{XI}$.

s CC $5,6,9,12,31$ y 32 .

${ }^{6} \operatorname{CsCV} 218$ y 317 .

${ }^{7} \mathrm{CC} 3$ y 8 .
}

Hispania, LVIL/3, núm. 197 (1997) 1009*1048 
La cuestión de la presidencia remite al tema de la jurisdicción o potestad de juzgar. ¿A quien corresponde? Según los preceptos carolingios de inmunidad, otorgados a la sede de Gerona y al monasterio de Sant Cugat, la potestad judicial correspondía a los obispos y abades en sus dominios ${ }^{8}$. Esta era la norma, que probablemente estaba en sintonía con la tradición hispanogoda, pero la realidad era más rica.

Hay juicios presididos conjuntamente por el obispo de Gerona y el conde de Ampurias o el conde de Besalú. A veces parece establecerse una distinción entre el obispo, que simplemente está presente (in presentia), y el conde que posee la jurisdicción (in iuditio) ${ }^{9}$. Esta dualidad o concurrencia puede explicarse por la propia naturaleza de los pleitos. En causas que atañen a bienes situados en villas del dominio episcopal, la jurisdicción corresponde al obispo, que preside los tribunales: In iuditio Servo Dei Gerundensis episcopus ${ }^{10}$. En cambio, en pleitos donde se cuestiona la pertenencia de tierras o villas al dominio de la sede, bien sea directamente, como hicieron los habitantes de Pals en 980 al sostener que su villa no era alodio de la sede, bien sea indirectamente "1, al discutir los términos de las villas episcopales y sostener que determinadas tierras estaban fuera de sus límites, se acudía a una jurisdicción distinta, en cierto modo imparcial o ajena a la cuestión como era la jurisdicción condal o en su defecto la vizcondal ${ }^{12}$. También puede explicarse el

8 Véanse estos preceptos en ABADAL, Ramon d', Catalunya carolíngia. II. Els diplomes carolingis a Catalunya, Barcelona, 1926-1950, 2 vols., págs. 106-151 y 183-200 y en CSCV 173. En todos ellos se encuentra la célebre cláusula de inmunidad: ut nullus comes, pontifex, iudex publicus, in predictis rebus habeat potestatem causas distringuendi nec obligandi, nec rationes exercendi, nec homines illorum aliquis distringat, nec per homicidium, nec per incendium vel raptum vel per ullum negocium (ABADAL, op. cit., pág. 200 y CC 173).

9 In presentia domni Gundemari sede Gerundense episcopo seu et in iudicio Adalarico comiti (CC 6). In presentia Teothario sedis Gerundensis episcopo vel in iudicio Delane et Soniario comites (CC 12)

${ }^{10} \mathrm{CC}$ 17. Otros juicios, presididos únicamente por el obispo de Gerona, en CC 14, 15, 16, 17, 18,22 y 23.

11 En el caso de los habitantes de Pals la causa se ditimió ante el tribunal del conde de Ampurias según explica el propio obispo de Gerona: mercedem dompni Gauzfredi comitis qui nobis dignatus est fieri de hominibus qui habitant in villa que dicitur Palaz qui scripturam falsissimam in eius iuditio protulerunt in contrarietatem scripte sedis (CC 59).

12 Unos pleitos del 921 y 1019 , cuyas causas cuestionan de hecho los términos de la villa episcopal de Báscara (del condado de Besalú), en sus limites con Vilademuls y Calabuig, se dirimen ante el tribunal de los condes Miró I y Bemat I de Besalú respectivamente (CC 32 y 78). Un pleito del año 888 , que afecta a los límites de la villa episcopal de Ullà (del condado de Ampurias), en sus límites con Torroella de Montgrí, se plantea ante el tribunal de los condes Dela y Sunyer de Ampurias (CC 12). En todos estos casos los oponentes de la sede pretenden reivindicar la plena propiedad de determinados bienes argumentando que se encuentran fuera de los límites de las villas episcopales. Un pleito del 841 , donde se dirime si un huerto está o no dentro del término de Báscara, es presidiđo por el obispo y un vizconde de nombre Guifré, que seguramente lo es de Gerona (CC 3). En esta época, y hasta finales del siglo $1 \mathrm{x}$ o principios del siglo $\mathrm{x}$, el condado de Gerona incluye la tierra de Besalú a la que pertenece Báscara, es lógico por tanto que en esta época el pleito se dirima ante la autoridad condal o vizcondal gerundense.

Hispania, LVI/3, nưm. 197 (1997) 1009-1048 
recurso al tribunal condal o vizcondal en casos donde se apela a un derecho superior, derivado de la potestad real. Este sería el caso de un cierto número de pleitos donde los oponentes de la sede argumentan sobre la propiedad de sus tierras en base al derecho de aprisión, de raiz visigoda, ratificado por los monarcas carolingios ${ }^{13}$. En estos casos se trata de saber qué debe prevalecer si el derecho de los aprisionadores sobre sus tierras (sicut ceteri ispani faciunt), que les convierte en propietarios o casi propietarios exentos de determinadas cargas fiscales, o el derecho de la sede en base a los preceptos carolingios de donación y confirmación de villas y tierras y de inmunidad, que se pretende anterior a las aprisiones. En general prevalece el derecho de la sede, que siempre exhibió como prueba irrefutable los preceptos carolingios de que disponía ${ }^{14}$. Naturalmente, la presencia de los obispos al frente de estos tribunales, junto a condes y vizcondes, no necesita justificación; son parte interesada en la causa, pero su presencia debe influir en el desenlace del juicio.

No muy distinta es la situación en los dos únicos juicios conservados que atañen al monasterio de Sant Cugat antes del año mil. El primero, del 988, lo presiden conjuntamente el abad sancugatense y el obispo de Gerona (In iudicio domno Gondemare, episcopo, et domno Odo, abba) ${ }^{15}$. El abad, como sabemos, tiene potestad de juzgar en su dominio inmune, pero quizá la naturaleza de la causa (un legado testamentario que el monasterio reclamaba contra un hermano del testador difunto y, por tanto, una propiedad que había que dilucidar si pertenecía o no al dominio) aconsejaba reforzar la autoridad del tribunal con la presencia de una de las máximas autoridades religiosas de Cataluña, el obispo Gotmar de Gerona, que, por otra parte, se había formado como monje en este monasterio. El segundo, del 996, contó con la asistencia del obispo Aeci de Barcelona, y el vicario Bonfill ${ }^{16}$. En este juició Odó, abad de Sant Cugat y obispo de Gerona, se enfrentó al vicario Seniofred de Rubi ${ }^{17}$. Aquí la relevancia social y política del oponente explica el recurso a un tribunal superior.

En las actas de los juicios, a continuación de los que convencionalmente hemos llamado presidentes de los tribunales (condes, obispos, abades, vizcondes y vicarios) vienen, en sentido estricto, los jueces, generalmente en número de tres o cuatro, pero excepcionalmente pueden llegar a ocho o diez, lo cual sucede en causas importantes, cuando en la presidencia de los tribu-

13 Es el derecho que asiste a los hispani inmigrados, en base al cual Carlomagno y sus sucesores les establecieron o aceptaron su establecimiento en Septimania y la Marca Hispánica, según los preceptos publicados por ABADAL, Diplomes, págs. X-XV y 305 y ss. Los origenes de la aprisión son visigodos puesto que se basan en la posesión legal de treinta años, regulada por la Lex Visigothornom $\mathrm{X}, 2,4$.

${ }_{14} \mathrm{CC} 8$ y 31. En algunos juicios los oponentes de la sede intentan reforzar su posición utilizando a la vez argumentos relativos a los términos entre villas y al derecho de aprisión: $\mathrm{CC} 9$ y 32 .

$15 \operatorname{CSCV} 218$.

16 El mismo que el 971 encabezó una embajada a la corte califal de Córdoba, según ABaDal, Ramon d', Els primers comtes catalans, Barcelona, 1965 (2.. ed.), págs. 318-319 y 337.

17 CSCV 317. 
nales hay dos máximas autoridades, la condal y la episcopal, y quizá porque cada una aporta sus expertos ${ }^{18}$. Se trata de técnicos en leyes, como bien dice en 968 el conde de Besalú y obispo de Gerona: iudicibus doctoribusque nostre legis consuluit ${ }^{19}$. Sin duda los nombra la autoridad competente, que ha de ser la condal y episcopal (y seguramente también la abacial en las abadías inmunes). Que los condes nombraban a los jueces de su tribunal se deduce del hecho de que en 980 el obispo de Gerona diga que el conde de Ampurias le ha hecho justicia ${ }^{20}$ : entendemos, por mediación de sus jueces. En este mismo sentido ha de interpretarse la definición que las actas dan de los jueces: aquellos a quienes está mandado juzgar (iudices qui iussi sunt iudicare), lo cual quiere decir que están a las órdenes de una autoridad superior que no puede ser otra que la condal (o, por delegación, la vizcondal) y los prelados inmunistas. Se les consideraba funcionarios públicos (iudex publicus) dotados de la potestad de juzgar (judiciaria potestate) garantizando el cumplimiento de las leyes, es decir, de los derechos y deberes individuales y colectivos ${ }^{21}$.

Los jueces dirigen de hecho los pleitos, secundados a veces por vizcondes y otros fieles condales: preguntan a las partes y a los testigos, examinan las pruebas y dictan sentencia. Al parecer algunos desempeñan su función durante años y alcanzan notoriedad. Es el caso de Homobonus, Ervigi Marc y Oruç (de los juicios del 988 y 996 de Sant Cugat) ${ }^{22}$, activos en medios cortesanos y episcopales de Barcelona. En Gerona, a finales del siglo IX, encontramos a unos mismos jueces que actuan en sucesivos juicios, seguramente porque gozan de la confianza de los prelados ${ }^{23}$. El papel de los jueces se afianza a lo largo de la documentación examinada hasta las primeras décadas del siglo $\mathrm{XI}$, sobre todo en aquellos pleitos que enfrentan a las máximas autoridades civiles y eclesiásticas de los condados o en conflictos de gran importancia. El 842, el obispo de Gerona y el conde de Ampurias pleitearon por el reparto de los impuestos de este condado, y lo hicieron ante una audiencia selecta de diez jueces que dirimió a favor de la autoridad episcopal en base a los preceptos carolingios y a la declaración de testigos ${ }^{24}$.

18 De la documentación examinada parece deducirse que la palabra juez se utilizaba en un doble sentido: de forma restringida, para referirse a expertos en leyes nombrados como jueces por la autoridad superior $y$, de forma general, para designar a todos aquellos hombres importantes que se sentaban en los tribunales. Esta última definición es congruente con lo expresado en la Lex Visigothorum donde se dice «que todo aquel que ha recibido la potestad de juzgar tiene el nombre de juez según la leym. Son jueces por tanto, los duques, condes, vicarios, jueces de paz (pacis adsertor), tiufados, milenarios, quingentenarios, centenarios, defensores, numerarios y uaquellos que son elegidos como jueces en los pleitos, ya sea por mandato real, ya sea por consenso de las partes" (H, 1, 27)

$19 \mathrm{CC} 55$.

20 CC 59.

21 La fórmula nullus judex publicus vel quislibet ex judiciaria potestate se repite sistematicamente en todos los preceptos de inmunidad (ABADAL, Diplomes, passim).

${ }^{22} \operatorname{CSCV} 218$ y 317.

${ }^{23} \mathrm{CC} 12,14,15,16,17,18$ y 22 .

24 CC 4 y 5.

Hispania. LVIL/3, núm. 197 (1997) 1009-1048 
Más decisiva debió ser la intervención del «colegio» de jueces de los condados de Besalú y Cerdaña hacia el 957, cuando el conde Sunifred de Cerdaña, recién pacificada la tierra de Besalú, donde unos rebeldes habían asesinado a su hermano, les consultó qué debía hacer con los bienes de tan «nefandísimos trangresores", y los jueces y doctores de la ley, "examinados los escritos de los venerables padres" (perspectis venerabilium patrum scriptis) sentenciaron a favor de la confiscación (dederunt sententiam) en base a su parecer y a la autoridad de la ley (per instantiam iudicum auctoritatesque legum) ${ }^{25}$.

Presidentes y jueces son arropados en su proceder por los boni homines que quizá, como se ha dicho muchas veces, son miembros de las principales familias del lugar donde se celebra la audiencia, aunque con más seguridad son miembros de las comitivas que acompañan a sus señores, los presidentes de los tribunales, por ello la nómina incluye a vassos dominicos y, en tribunales de presidencia eclesiástica, a muchos clérigos (arcedianos, arciprestes, levitas, presbíteros). Su presencia refuerza la presidencia del tribunal, sobre todo en causas que le conciemen. Esto no excluye que en algún documento el escribano utilice la expresión boni homines para designar al conjunto de los asistentes, de los que menciona los más significativos, y se refiera al resto con expresiones genéricas: alionum multorum bonorum hominum qui ibidem aderant ${ }^{26}$. Testigos aparentemente mudos de lo que sucede, los boni homines pueden jugar un papel de enlace entre la potestad judicial y los gobernados. Con su presencia dan fe, suponemos, del correcto proceder del tribunal, garantizan la divulgación de la sentencia y pueden ser testigos de todo ello en el futuro ${ }^{27}$.

La referencia a los boni homines se cierra regularmente con la mención del sayón, una figura que, como todo el proceso judicial, viene del pasado hispanogodo y que, como se sabe, estaba encargado de mantener el orden, asegurar la comparecencia de acusados y testigos y garantizar la aplicación de las sentencias ${ }^{28}$.

Las audiencias, dicen los documentos, son públicas (placitum o mallum publicum) y ello, creemos, debe entenderse en el sentido de que los jueces escuchan y dirimen en ellas todas las causas que se les plantean siempre que estén sujetas a la ley ${ }^{29}$. No está clara en cambio la posibilidad de que fueran

$25 \mathrm{CC} 55$. «Los escritos de los venerables padres» creemos que no pueden ser otros que los títulos de la Lex Visigothorum o bien los textos canónicos.

$26 \mathrm{CC} 4$

27 En la Lex Visigothorum los boni homines son personas a las que se recurre para establecer el precio justo en una indemnización (por la muerte de un esclavo) o en reparto de bienes (la descendencia de una pareja de esclavos de distintos dueños) (VI, 1, 5 y X, 1, 17).

${ }_{28} \mathrm{CC} 1,4,5,9,12,14,15,16,17,18,22,23,31$ y 32 . Un sayón, de nombre Undila, aparece en diversas actuaciones judiciales de los años $892-893$ siempre en audiencias presididas por el mismo obispo, lo cual avala la idea de que los prelados inmunistas, y por supuesto los condes, formaban sus propios tribunales, es decir, nombraban a jueces y sayones. Sobre el sayón en la Lex Visigothonum véase II, 1, 18; II, 1, 26; Il, 2, 4, etc.

29 La Lex Visigothorum establece ut nulla causa a iudicibus audiatur, que in legibus non contintetur (II, 1, 13). 
abiertas a la asistencia de personas ajenas a las causas que se juzgaban, sobre todo a la asistencia masiva de curiosos. La Lex Visigothorum más bien parece indicar lo contrario cuando dice que "la audiencia no ha de ser perturbada por alborotos o gritos, sino que, dejados de lado los que no intervienen en el pleito, sólo deben tener acceso al juicio aquellos que consta que han de estar presentes» ${ }^{30}$. Claro que la misma ley otorga a los jueces la potestad de escoger auditores que esten presentes y eventualmente ayuden con el consejo. La documentación conservada no precisa sistemáticamente los lugares donde se celebraban las audiencias. Sabemos, no obstante, de juicios que tuvieron lugar en villas o ciudades condales o episcopales (Vernet, Ampurias, Besalú, Gerona, Barcelona), probablemente en los propios palacios residencia de condes, vizcondes o obispos, en salas de audiencia y en iglesias palatinas o castrales ${ }^{31}$. Algunos juicios o sesiones de juicios se celebraban en villas que no tenían especial relevancia administrativa, quizá en la propia plaza pública ${ }^{32}$. Las iglesias parecen jugar un papel relevante en los juicios, sin duda porque aportan al pleito una dimensión sagrada, con la que probablemente se pretende comprometer a los hombres en la verdad y el recto proceder. Los testigos, antes de testificar, juran atenerse a la verdad, y lo hacen, según costumbre, tocando un objeto sagrado, a veces poniendo las manos sobre un altar ${ }^{33}$. Es más que probable que algunos juicios se celebren en las propias zonas de conflicto, quizá para facilitar la comparecencia de las personas afectadas y los testigos. No sabemos de la periocidad de las audiencias, pero algunos documentos sugieren que cuando los tribunales se reunían era para escuchar muchas causas ${ }^{34}$, y es evidente que la complejidad de las causas exigia muchas veces la celebración de varias audiencias.

La mecánica del pleito, estaba notoriamente ensayada, es decir, venía de antiguo, sin duda de la época visigoda, como de esta época procedía el código legal de referencia, la Lex Visigothorum, al que hay que añadir los preceptos

30 Lex Visigothorum II, 2, 2 (Ut nullo audientia clamore aut tumultu turbetur).

31 El 874 se celebró un juicio en la iglesia de Vernet sobre la libertad o esclavitud de un hombre y su familia, audiencia presidida por el conde Miró I (MarCa, Petrus de, Marca Hispanica sive limes hispanicus, Paris, 1688, ap. 34. El juicio del 842 entre el obispo de Gerona y el conde de Ampurias tuvo lugar en la ciudad de Ampurias (CC 5).

32 Tal es el caso de un juicio del 881 presidido por el obispo de Gerona y el conde de Ampurias que tuvo lugar in villare quod dicitur Purtos quod est in territorio Impuritano in mallo publico (CC 9).

33 Ocho testigos de un juicio del 817 juran con las manos puestas sobre el altar de san Andrés de la iglesia de Borrassà del condado de Besalú con estas palabras: per Deum Patrem omnipotentem et per thesum Christum filium eius et per Spiritum Sanctum qui est in Trinitate unus et verus et ad locum venerationes Sancti Andree que fundata est in villa Borraciano in territorio Bisuldunense, super cuius sacrosanclum altare has conditiones manibus nostris continemus vel iurando contangi. mus... (CC 1). La misma escena, con parecidas palabras, se repite ante el altar de san Martín de la iglesia de Ampurias en el célebre juicio del 842 (CC 4).

34 Algunos documentos explican que los tribunales se constituian in mallo publico pro multorum causas ad audiendum et rectis et iustis iuditits ad diffiniendum (CC 5 y 9).

Нispania, LVIJ/3, núm. 197 (1997) 1009-1048 
carolingios como fuente de derecho. Los jueces llevan adelante los pleitos, según costumbre, y con muy escasas variaciones ${ }^{35}$. Constituido el tribunal, escuchan las demandas de parte (petitiones) formuladas por los interesados o, en el caso de personas importantes (condes y obispos), por sus procuradores (mandatarius, assertor, advocatus) ${ }^{36}$. En tribunales del obispo de Gerona y en causas promovidas por el prelado actuan, como procuradores, presbíteros y arciprestes e incluso un juez, vasallo del obispo: Autatus qui iudex est subditus vel assertor de supradicto episcopo ${ }^{37}$. En causas promovidas por el conde que afectan a su patrimonio o a sus ingresos, todavía considerados de algún modo (al menos formal) riqueza pública, el procurador es denominado mandatarius ad causas fiscales requirendas ${ }^{38}$. En todos los casos, la Lex establece que quien no defienda una causa por sí mismo sino por medio de terceros debe delegar por escrito a su representante ${ }^{39}$, un requisito que sin duda todavía se cumple en época carolingia en Cataluña.

Formulada la petitio, el tribunal se dirige a la parte contraria, la acusada, y la interroga sobre el contenido de la acusación: tunc supradicti vicecomites vel iudices interrogavimus ${ }^{40}$. Oida la acusación y la defensa, el tribunal, según establece la ley, solicita pruebas escritas y testigos orales a ambas partes ${ }^{41}, y$ para ello a veces refuerza su solicitud con la citación más o menos literal de la Lex ${ }^{42}$. Por ejemplo, en el juicio del 874 , los jueces dijeron que, según la Lex, quien acuse a un hombre de ser esclavo debe aportar las pruebas de su escla-

35 A la existencia de prácticas judiciales consuetudinarias se refieren los preceptos carolingios en sus cláusulas de inmunidad: ut nulus judex publicus vel quislibet ex judiciaria potestate... in aecclesias aut loca vel agros seu reliquias possessiones memoratae sedis...ad causas judiciario more audiendas vel discutiendas...ingredi audeat (ABADAL, Diplomes, passim).

36. Por una razón de prestigio y de protección frente a un eventual desgaste del principio de autoridad, la Lex Visigothonum establece que principum et episcoporum negotia non per se, sed per subditos sint agenda (II, 3, 1). Subditus tiene el settido de vasalio o fiel.

${ }_{37} \mathrm{CC} 9,14-18$ y 31 .

38 Así sucede con el procurador que en nombre del conde Miró I del Conflent el 874 reclamó en juicio a un tal Llorenç como servus fiscalis (MARCA, op. cit., ap. 34).

39 Lex Visigothorum II, 3, 3.

$40 \mathrm{CC} 8$.

41 La Lex Visigothorum establece que «el juez, a fin de conocer bien la causa, primero debe interrogar a los testigos, $y$ después pedir los documentos a fin de que se pueda descubrir la verdad con toda certeza y no se tenga que llegar fácilmente al juramentos (II, 1, 23). Dudamos de la exacta interpretación de esta ley en cuanto al orden en el procedimiento. De la documentación catalana examinada creemos poder deducir que los jueces primero escuchaban a las partes, después examinaban los documentos y finalmente interrogaban a los testigos. Al fin y al cabo éste parece un proceder práctico. En todo caso la Lex Visigothorum establece que las pruebas deben exigirse a ambas partes: Quod ab utraque causantium parte sit probatio requirenda (II, 2, 5).

42 En el juicio del 842 sobre los impuestos del condado de Ampurias, los jueces glosaron el contenido de la Lex Visigothorum (II, 5, 2) con la frase Ab utraque parte sit probatio requirenda, tam a petente quam ab eo qui petitur iudex causam debeat recipi (CC 5), que no es la fórmula literal, pero traduce un buen conocimiento de la norma.

Hispania, LVI/3, nủm. 197 (1997) 1009-1048 
vitud y, a su vez, el acusado de esclavitud que se pretenda libre debe aportar las pruebas de su libertad ${ }^{43}$.

Las escrituras son examinadas con atención a fin de comprobar si se cumplen los requisitos que estable la ley (datación claramente expresada y suscripciones del autor y de los testigos) ${ }^{44} \mathrm{y}$ consecuentemente pronunciarse sobre su validez o invalidez. En este sentido, los tribunales de los siglos IX y $\mathrm{x}$, e incluso los de comienzos del siglo $\mathrm{XI}$, tuvieron gran respeto por los preceptos carolingios, exhibidos, como decíamos más arriba por la sede gerun. dense. Frente a la sede, particulares y comunidades presentan también sus escrituras. Con la pretensión de sustraer sus tierras al dominio de la sede, los campesinos de Pals mostraron, al parecer, una escritura que no presentaba los requisitos legales de validez y que el tribunal consideró "falsísima" ${ }^{45}$.

Más frecuente es la actuación de individuos que, contra el derecho global de la sede sobre determinadas villas, argumentan un derecho particular sobre propiedades concretas sitas dentro de los términos de estas villas, derecho que basan en operaciones de compra efectuadas a particulares tiempo atrás ${ }^{46}$. Frente a estos intentos de consolidar propiedades particulares en el seno del dominio episcopal amparándose en el derecho que asiste a todo comprador, el proceder del tribunal fue siempre el mismo: antes de desautorizar la escritura de compra-venta presentada, se preguntaba a los acusados $u$ oponentes de la sede si podían presentar a sus auctores para que dieran fe de la legitimidad de la venta por ellos efectuada: interrogaverunt me ... supradicti iudices si potebam exinde auctores legitimos habere. Era un proceder perfectamente coherente con la Lex, que dice "que nadie (ningún comprador) puede negarse a responder a un demandante por el hecho de que éste no haya presentado su causa ante el auctor (vendedor)" ${ }^{77}, \mathrm{y}$ añade que en caso de compra de cosas robadas sin saberlo o a sabiendas, el comprador debe presentar el auctor (vendedor) al juez ${ }^{48}$. Y, para presentarlo, el tribunal daba varios plazos o varias audiencias de plazo: dederunt mihi - dice un particular-supradicti iudices plures placitos, unum et alium et tertium ${ }^{49}$. Finalmente, si el acusado no presentaba auctores legitimos y aceptaba que in nullo placito auctorem exinde habere non possum, el tribunal declaraba la invalidez e ilegalidad de la escritura presentada: ista scriptura ... invalida est et non legibus vallata ${ }^{50}$. Esto bastaba muchas veces para sentenciar.

${ }^{43}$ Si quis ingenuum ad servitium addicere voluerit, ipse doceat quo ordine ei servus advenerit; et si servus ingenuum se esse dixerit, et ipse simili modo ingenuitatis sue firmam ostendat probationem (Lex Visigothorum V, 7, 8). El acta del pleito en MARCA, Marca Hispanica, ap. 34.

44 Estos requisitos se encuentran en la ley Quales debeant scripture valere (Lex Visigothorum II, 5, 1).

45 CC 59.

46 CC $15,16,17,22$ y 23 .

47 Lex Visigothorum II, $2,1$.

48 Lex Visigothonum VII, 2, 8 y VII, 2, 9 (Si quis rem furtivam sciens a fure conparaverit, ille, qui, emit, suum representet autorem et postea tamquam fur conponere non moretur).

49 CC 23.

so CC 16 y 23.

Hispania, LV11/3, núm. 197 (1997) 1009-1048 
Cuando no había escrituras o éstas no eran prueba suficiente se recurría a testigos, presentados por las partes ${ }^{51}$. Como decíamos más arriba, al iniciar su declaración, los testigos juran por Dios Padre, su hijo Jesucristo y el Espíritu Santo, y con las manos puestas sobre reliquias sagradas, que conocen y saben bien y de verdad, y estaban presentes cuando acontecía lo que declaran 52. La declaración finaliza con una ratificación de rectitud y veracidad garantizada por el juramento prestado: et ea que scimus recte et fideliter testificamus per supra dictum iuramentum in Domino ${ }^{53}$. Finalizada la declaración de testigos de una parte, el tribunal preguntaba a la parte contraria si tenía algo que objetar o reprobar contra tales testigos ${ }^{54}$, o si tenía más y mejores testigos cuyo testimonio pudiera invalidar el precedente ${ }^{55}$.

Si la parte contraria reconocía no tener nada que objetar a los testigos de su oponente (nichil habeo de infamia vel de obiectu), ni podfa presentar más y mejores testigos, el tribunal daba por cerrada la aportación de pruebas y sentenciaba: decrevimus iudicium et ordinamus, leemos en algunos documentos; dederunt sententiam consta en otros ${ }^{56}$. Naturalmente, la sentencia en estos casos consistía en dar la razón a una parte y quitársela a otra, de ahí que los jueces se dirigieran a la parte perdedora exigiéndole que acatara por escrito el resultado del pleito en forma de acta de renuncia (professio, exvacuatio, deffinitio, recognitio) a sus pretendidos derechos: tunc mandaverunt exinde scribere me professione ${ }^{57}$. No obstante, llegados al punto final en que una parte se quedaba sin argumentos o sin pruebas, debía ser frecuente que esta parte asumiera la derrota sin tener que recurrir a una sentencia firme o a un mandato

sI En la concurrencia de pruebas ante un tribunal, la superioridad de la escritura legalmente otorgada, frente a las declaraciones contrarias de testigos, está claramente expresada en la legislación visigoda: De investiganda iustitia, si aliut loquatur testis, aliut scriptura (Lex Visigothorum II, 4, 3).

52 También en esto se sigue escrupulosamente la Lex Visigothorum: Quod testibus sine sacramento credi non possit $(\mathrm{II}, 4,2)$.

$53 \mathrm{CC} 1$ y 4

54 La pregunta también estaba justificada por la ley puesto que, según la Lex Visigothorum, no podian testificar los homicide, malefici, fures, criminosi sive venefici, et qui raptum fecerint vel fal. sum testimonium dixerint (II, 4,1 ). Existe además una ley concreta sobre la imposibilidad de presentar como testigos a los culpables de falso testimonio $(\mathrm{Hl}, 4,6)$.

${ }_{35}$ Hoc testimonium datum tunc interrogavimus ipsum... si habebat aliquid de obiectu vel reprobacione quod contra ipsos testes dicere debeat, aut meliores vel pluriores testes pro quibus illi reprobi sint aut illorum testimonium invalidum esse debeat (CC 5). Tunc nos supradicti judices Sesenando diximus; Potes alios habere testes ampliores aut meliores aut crimen quod in lege vetitum est testificandi dicere hodie aut postmodum? Et ille in suis responsis dixit: Non posstum habere testes nec scripturas nec ullum judicium veritatis unde istos testes diffamare possim (MARCA, Marca Hispanica, ap. 34). Una variante del examen de escrituras y de la declaración de testigos en tierras de límites disputados podia ser la mensuratio, es decir, el recorrido por los términos del predio en disputa y su medición, que efectuaban jueces y testigos, de acuerdo con procedirnientos de antigua tradición romano-goda, según recuerda nuestra propia documentación: sicut lex gothorum commemorat (CC 9).

S6 CC 5 y 55 .

$57 \mathrm{CC} 8$. 
imperativo de exvacuación, que de otro modo inevitablemente se produciría. Quizá es por ello que en la mayoría de los juicios, después del examen de las escrituras y de las declaraciones testificales, y del reconocimiento de una parte de no tener más y mejores pruebas, esta misma parte automáticamente se exvacuaba: Sic me recognosco vel exvacuo ab interrogatione judicum et praesentia bonorum hominum in villa Verneto in ecclesia sancti Saturnini 58.

De los procesos examinados sólo hay un caso que escapa a la norma. Nos referimos al juicio a que, el 988 , fue sometido un particular, Sentemir, a quien el abad de Sant Cugat acusaba de ocultar el testamento de su hermano que dejaba sus propiedades al cenobio. Sentemir argumentaba desconocer el paradero de dicho testamento frente a la declaración de un sacerdote testigo que juraba haberlo encontrado en un archivo y entregado a Sentemir para que lo presentara al juez. Sin pruebas escritas ni testigos, Sentemir debería haber aceptado la declaración del sacerdote y exvacuarse, pero persistió en la negativa (noluit professionem suam exinde facere) a pesar de los insistentes ruegos y advertencias de los jueces. Finalmente, antes que el tribunal dictara sentencia, pidió el juicio de Dios por ordalía de agua hirviente (Dei iudicium petens per examine caldaria), convencido, según decía, de que superaría la prueba. No fue así, y tuvo que confesar que había dado el testamento a su mujer para que lo quemara. Hecha la recognitio y cuando era entregado al mandatario del abad para que expiara su culpa con la esclavitud, implonó misericordia y se le condonó la pena por una multa ${ }^{59}$.

La prueba caldaria figura en una ley de la edición de la Lex que manejamos ${ }^{60}$, pero Aquilino Iglesia ha explicado que esta ley no figura en todos los manuscritos de la Lex, y que muy bien puede ser un añadido posterior, del siglo Ix o x. Él la llama pseudoley ${ }^{61}$. En efecto, el conjunto de la Lex es ajeno, por no decir, opuesto a las ordalías, y sorprendería que este códice tuviera en sus origenes una ley referente a la ordalía caldaria y no regulara su aplicación. La aparición tardía de esta prueba en Cataluña (así como su aparición algo anterior en el área castellanoleonesa) puede, pues, interpretarse ya como un primer indicio de desnaturalización de la justicia de tradición hispanogoda. Y ello aunque el juez de la causa fuera Homobonus, uno de los juristas prestigiosos de la época, y autor probablemente de un manuscrito de la Lex ${ }^{62}$. El problema reside entonces en saber de donde procede esta ordalía y otras

58 MARCA, Marca Hispanica, ap. 34.

59 CSCV 218.

to Liber Iudiciorum sive Lex Visigothorum. Ed. Monumenta Germaniae Historica. Legum Sectio I. Leguum Nationum Germanicorum, HANNover, T. I., 1902. Es la Lex VI, 1, 3 (Quomodo iudex per examen caldarie causam perquirat).

61 IGLESIA, Aquilino, El proceso del Conde Bera y el problema de las ordalías, Madrid, 1980, págs. 82 y ss.

62 VAlLs-TABERnER, Fernando, «El Liber iudicum popularis de Homobono de Barcelona», en Obras Selectas. II. Estudios histórico-jurídicos, Madrid-Barceiona, 1954, págs. 235-246, y MuNDó, Anscari M., «El Liber iudicionum a Catalunya», en Documents jurídics de la història de Catalunya, Barcelona, 1991, págs. 13-30.

Hispania. LVIJ/3, núth. 197 (1997) 1009-1048 
(duelo judicial, ordalía del agua fria) que encontramos en procesos catalanes del siglo XI. Aunque quizá no puede descartarse del todo la existencia de formas extrajudiciales de resolución de conflictos (entre las cuales las ordalías) en la España visigoda, es posible, como quiere Aquilino Iglesia, que su origen fuera posterior, a través de influencias francas o más bien de la propia evolución sociojurídica y mental de la sociedad hispanogoda. De sus argumentos, interesa retener, en primer, lugar la idea de un clima religioso preordálico (en consonancia con los avances de la cristianización) que tendía a considerar a Dios como la fuente de toda justicia ${ }^{63}$, y a confiar en su intervención cuando los recursos humanos resultaban insuficientes. $Y$, en segundo lugar, la idea de que durante el siglo x y a comienzos del xI la justicia tradicional se desgastaba y cada vez era más incapaz de evitar el perjurio. Entonces, pensamos nosotros, es explicable que una justicia ejercitada por clérigos admitiera, con todas sus dudas, el recurso al juicio de Dios (la ordalía). Lo que quizá entonces hombres como Homobonus no podían sospechar es que, andando por la pendiente, su sistema judicial acabaría por caer.

La mayor parte de la documentación examinada trata de conflictos que podemos dividir en horizontales y verticales. Por conflictos horizontales entendemos los que enfrentaron a hombres o instituciones de parecido poder o influencia, generalmente miembros de la aristocracia laica y eclesiástica, entre sí. Disputas, por ejemplo, entre linajes condales y vizcondales ${ }^{64}$, entre condes y potentes ${ }^{65}$, entre descendientes de antiguos condes y fieles de nuevos condes ${ }^{66}$ y entre la Iglesia y la aristocracia ya sea por la posesión de villas ${ }^{67}$ ya sea por la posesión de rentas o impuestos ${ }^{68}$. En cuanto a conflictos verticales, los más conocidos son los que afectan a condes, obispos y abades, por un lado, y a comunidades campesinas, por otro. En ellos generalmente se plei-

63 El conde de Besalú y obispo de Gerona Miró Bonfill escribe en el acta de dotación del monasterio de Sant Pere de Besalú, el 978: cum igitur Deus justitia sit (citado por IGLESIA, op. cit., pág. 209).

64 La confiscación de los bienes de un vizconde considerado traidor en ABadal, Diplomes, págs. 77 y 391 .

is La confíscación de los bienes de unos rebeldes a la autoridad condal en SaLrach, Josep Maria, «El comte Guifté de Besalú i la revolta del 957 , Amics de Besalú. II Assemblea d'Estudis del seu comtat, Olot, 1973, págs. 3-30.

65 Pleito del 862 por la posesión de la villa de All, en la Cerdaña, entre un descendiente del conde Aznar Galindo y un fiel del conde Salomó, en TragGia, Joaquín, «Discurso histórico sobre e] origen y sucesión del reymo pirenaico hasta don Sancho el Mayon, Memorias de la Real Academia de la Historia, IV-3, 1805, págs. 56-57.

67 Disputa por la posesión del vilar de Mata del Conflent entre un fiel del conde Salomó y el monasterio de la Grassa el 865, en ALART, Benjamin, Cartulaire Roussillonnais, Perpignan, 1880, págs. 1-6.

68 Al juicio del 842 entre el obispo de Gerona y el conde de Ampurias (CC 4, 5 y 6), cabe añadir un juicio del 961 entre el obispo de Urgel y un señor local por la posesión de los diezmos y primicias de All (Baraur, Cebrià, «Els documents dels segles IX i X, conservats a l'Arxiu Capitular de 1a Seu d'Urgell», Urgellia, II, 1979, doc. 143).

Hispania, LV[1/3, núth. 197 (1997) 1009-1048 
tea por la posesión de tierras y la satisfacción de cargas fiscales o rentales ${ }^{69}$ : conflicto entre la abadesa de Sant Joan de les Abadesses y unos quinientos campesinos de unas veinte villas y villares del Ripollès en $913^{70}$; entre veinticuatro campesinos de Juïgues y el monasterio de Ripoll en $983^{71}$; entre campesinos de Bàscara y de Palaz y la sede de Gerona en 921 y 980 respectivamente 72 ; entre un centenar de campesinos de Artés y la sede de Vic en $9388^{73}$; entre los campesinos de Vilamacolum y el conde de Ampurias en $916^{74}$; entre unas cuarenta y cinco familias campesinas de Vallformosa y el conde de Barcelona, Gerona y Ausona en $977^{75}$, etc. Junto a estos pleitos, en los que los poderosos se enfrentan a colectivos campesinos, lo que todavia da cierta fuerza a éstos y explica que en algunos casos salgan ganadores, existen numerosos litigios entre instituciones religiosas y particulares (campesinos o hacendados locales), que inexorablemente pierden los juicios, y con ellos sus tierras ${ }^{76}$.

Naturalmente los conflictos verticales son desiguales, no únicamente porque enfrentan a gobernantes y gobernados, hombres de distinta posición social y política, sino también porque frecuentemente los «inferiores» son llevados a juicio y juzgados por los «superiores», es decir, sus propios adversarios. Importa poco que los presidentes de los tribunales enmascaren su condición de parte interesada en los juicios encomendando a mandatarios la defensa de su causa, y que juzguen rodeados de jueces expertos. El hecho es que los componentes de los tribunales son sus agentes o vasallos, lo cual pone en entredicho la imparcialidad de la justicia. Es cierto que la sujeción de todos a un mismo código jurídico citado hasta la saciedad ${ }^{77}$, el seguimiento de procesos regulares que obligaba a presentar pruebas escritas y testigos y la presencia de numerosos auditores eran normas públicas, en el sentido de obli-

69 Hay quien pretende discutir la existencia de comunidades campesinas en esta época. La comunidad campesina no necesita ser jurídicamente pensada ni regulada por escrito para existir. Es la necesidad lo que la construye, y los documentos de que disponemos no fueron escritos precisamente para hablarnos de ella. Ya es mucho que aparezca de soslayo reflejada en algunos juicios cuando se siente agredida.

70 UDINA, Federico, El Archivo Condal de Barcelona en los siglos $X X+X$, Barcelona, 1951, doc. 38

71 Marqués, Jaime, «Sobre los antiguos judios de Gerona», Sefarad, XXIII-1, 1963, págs. 22-35.

72 CC 31 y 59.

73 JUNyent, Eduard, Diplomatari de la catedral de Vic, 4 fasc., Vic, 1980-87, doc. 182.

74 Simó, M. L., «Aportación a la documentación condal catalana (siglo X)», Miscelánea de Estudios dedicados al profesor Antonio Marín Ocete, Granada, 1974.

75 UDINA, op. cit., doc. 181

${ }^{76}$ La mayor parte de los juicios de los siglos $\mathrm{Ix}$ y $\mathrm{x}$, recogidos en el CC, son de este tipo: $\mathrm{CC}$ $1,3,8,9,12,14,15,16,17,18,22$ y 23.

77 No hemos hecho aquí un seguimiento sistemático de las numerosas citas de la Lex en la documentación procesal de los siglos IX y $\mathrm{X}$, pero han aparecida algunas, a las que podriamos añadir una, muy explícita, del 862, que muestra como los jueces se apoyaban en la Lex para dictar sentencia: Tunc ipsi meminiti iudices perquisierunt in libro gotorum, et invenerunt in libro quarto, titulo secundo, era nona decima, ubi dicit: Ut qui filio non reliquierit, faciendi de rebus suis quod voluerit, abeat potestatem (TraGgiA, op. cit., págs. 56-57).

Hispania, LV[1/3, nưm. 197 (1997) 1009-1048 
gado cumplimiento por todos y para todos, que tenían por misión limitar las arbitrariedades. No obstante, con matices, podría decirse que aquella justicia pública tenía contenido de clase en el sentido de que era administrada por jueces que, en sentido amplio (condes, prelados, vizcondes, vassi dominici, jueces propiamente dichos y sayones), eran potentes, miembros de la clase gobernante, vinculados entre sí por lazos de obediencia, fidelidad y servicio. Estos lazos, que podríamos llamar de carácter feudo-vasallático, por los compromisos personales y la relación de dones y contradones que comportaban. operaban en un marco público, en el sentido de que servían de cimentación a un edificio que todavía reconocía un sólo principio de autoridad del que formalmente derivaban las delegaciones de poder y el pago de servicios (con bienes del fisco y cargas públicas). Contenido de clase (o de casta, como prefiere decir Bonnassie) también porque la Lex se enseñaba en escuelas de la Iglesia, donde se formaron los expertos (jueces, mandatarios) que juzgaron a campesinos enfrentados a obispos y abades por la posesión de tierras. Contenido de clase también porque el documento escrito, prueba suprema ante los tribunales, era siempre obra de clérigos, cuyos servicios pagaban más fácilmente los poderosos que los débiles. Y contenido de clase, finalmente, porque antes del año mil los tribunales todavía consideraban los preceptos carolingios como el supremo título jurídico, que daba prelacía a los derechos de propiedad de quien los poseía, frente a sus oponentes, y es obvio que la cancillería real no otorgaba estos diplomas a cualquiera, sino a potentes, fieles laicos y eclesiásticos, colaboradores en el gobierno ${ }^{78}$.

A nuestro entender, la continuidad y desgaste de una justicia de antigua tradición pública, durante el siglo $\mathrm{x}$ y comienzos del $\mathrm{xI}$, es un fenómeno común a todas las regiones situadas entre los Alpes y Galicia, incluso en regiones del sur de Francia donde no se aplicó la Lex Visigothorum. Naturalmente, las particularidades regionales son importantes y, ciertamente, la crisis de la justicia tradicional empezó en unas regiones antes que en otras. En este sentido, Cataluña puede ser un ejemplo extremo de continuidad. La explicación ha de estar en un sistema social donde los poderosos todavía no acaparan todo el poder y la riqueza y existe una idea o un principio de autoridad sobre el que puede sostenerse un sustrato jurídico romano, que las aportaciones germánicas no desnaturalizaron completamente. Un sustrato, que en cuestiones esenciales (como la idea de la potestad, garante del derecho y de la justicia), en la zona comprendida entre Cataluña y Provenza, pudo revitalizarse merced al dominio carolingio. Los estudios que se han hecho sobre la administración de justicia en Provenza, Auvernia y Cataluña así parecen indicarlo ${ }^{79}$.

78 Por supuesto, incluimos en la categoria de potentes a los hispani personalmente agraciados con preceptos carolingios, que llegaron a Septimania y la Marca y aqui se afincaron con sus dependientes, fieles y esclavos.

79 PoLy, Jean-Pierre, La Provence et la société féodale, 879-1/66, Paris, págs. 43 y ss.; LaURANSON-Rosaz, Christian, L'Auvergne el ses marges -Velay, Gévaudan-du vmr" au xt' siècle. La fin du Monde Antique?, Le Puy-en-Velay, 1987, págs. 343 y ss., y BONNASSIE, Pierre, La Catalogne du milieu du $X^{*}$ à la fin $d u$ Xf siècle, I, Toulouse, 1975, págs 183-201. 
Pero incluso fuera del mundo carolingio, en Aragón, Navarra y la Castilla del Arlanza y el Arlanzón, donde la Lex siguió siendo, como en Cataluña, el código de referencia, la continuidad también es fuerte, aunque en regiones como Navarra se observa una práctica grosera y empobrecida de esta justicia de tradición pública ${ }^{80}$. Más allá, en el primitivo reino de León, es probable que la degradación del proceso judicial hispanogodo se produzca antes. Aquilino Iglesia así lo cree, y es interesante su argumento que relaciona la aceleración de la crisis de la Lex con la desaparición del poder político central en la zona ${ }^{81}$. No menos interesante es observar, siguiendo a José María Mínguez, corno esta involución de la justicia se produce a través de los propios canales de la mecánica tradicional del pleito, desvirtuando las normas de la Lex y abusando de su interpretación en favor de los poderosos ${ }^{82}$. Podríamos decir que la justicia, cuando operaba en un marco donde de grado o por fuerza existía una autoridad central y un consenso sobre un sistema de valores que preservaba la nocion de derechos y deberes colectivos, esta justicia, sin perder su naturaleza de clase, reconocía sus propios límites. En cambio, cuando la autoridad central y/o el consenso se desgastaban, las contenciones cedían y la crisis de la justicia se precipitaba. Esto pasó en todas partes, entre los Alpes y Galicia, pero, como decíamos, en unas regiones antes que en otras ${ }^{83}$.

\section{CONTINUIDAD Y CRISIS}

Respecto a los primeros decenios del siglo $\mathrm{XI}$, los documentos selecciona dos del CSCV conciernen en gran medida a pleitos importantes que enfrentan al monasterio con laicos poderosos. Quizá por ello, es decir, por la relevancia social de la parte contraria, y por la naturaleza de las causas, el abad nunca administró justicia por sí mismo, sino que, con excepciones, acudió a la corte.

Compareció ante el tribunal del conde Ramon Borrell y la condesa Ermessenda, del que formaban parte obispos, optimates y jueces, al menos cinco veces entre 1011 y 1017. Ante esta audiencia se querelló por la posesión de la torre de Moja y el castillo de Albinyana con la familia vizcondal ${ }^{84}$, y por la

\footnotetext{
${ }^{80}$ Así parecen indicarlo las tesis de LaRrea, Juan José, Peuplement et société en Navarre de la fin du ntonde romain à l'âge féodal ( $N^{*}$-XIF siècles), Université de Toulouse-Le Mirail, 1994, págs. 417-433 - en prensa-, y PASTOR DíAZ DE GARAYo, Ernesto, Castilla en el tránsito de la Antiguiedad al Feudalismo, Valladolid, 1996, págs. 183-200.

81 lGLESIA, op. cit., pág. 216.

82 Minguez, José Maria, «Justicia y poder en el marco de ła feudalización de la sociedad leonesay, en La giustizia nell Alo Medioevo (secoli $I X-X I$ ), Settimane di Studio del Centro ltaliano di Studi sull'Alto Medioevo, Spoleto, 1997, págs. 491-548.

83 Atendiendo a otros aspectos de la evolución social, hemos expresado estas mistras ideas en "Les féodalités: 1/ Des Alpes à la Galice», en Poly, Jean Pierte, et Bournazel, Eric, Les féodalités, Paris (Presses Universitaires de France), en prensa.

84 CSCV 437 y 439.

Hispania, LVII/3, núth. 197 (1997) 1009-1048
} 
posesión de los yermos y estanques de Calders (Baix Penedès) con la familia vicarial de los Santmartí ${ }^{85}$. En el primer caso los derechos del cenobio, que se basaban en una donación testamentaria, prevalecieron sin dificultad. El segundo fue más complejo: el abad basó su derecho en preceptos carolingios ${ }^{86}$ y sus oponentes en los derechos derivados de la aprisión efectuada por un antepasado. El tribunal dudó y, en un primer juicio, propuso que las partes llegaran a un acuerdo. La avenencia no fue posible y en un segundo juicio el tribunal, que persistía en sus dudas, sugirió al conde que arbitrara la querella, lo que hizo Ramon Borrell, compulsus timore Domini, a favor de Sant Cugat.

El abad compareció también ante el tribunal de la condesa Ermessenda al menos cinco veces también, en los años 1018-1037, para tener pleito con el vicario Seniofred de Rubí, el vizconde Adalbert del Rosellón y Bernat Otger, un magnate de la Marca del Penedès ${ }^{87}$. Pero la corte de Barcelona no sólo examinó litigios que enfrentaban a Sant Cugat con familias aristocráticas, sino que también sentenció en causas menores relativas al incumplimiento de legados testamentarios, la ruptura unilateral de las condiciones de tenencia y la usurpación de bienes ${ }^{88}$. La impresión es que la justicia condal funciona regularmente en Barcelona (in Barchinona civitate, in comitali palacio) hasta 1037 al menos. De hecho, no hacía falta que el conde presidiera los tribunales para que la justicia funcionara. Estaba el tribunal del obispo, que actuó en 1030 en un pleito entre la familia vizcondal y el abad por la posesión de un alodio de los términos del castillo de Claramunt ${ }^{89}$, y el recurso a tribunales sin presidencia singular formados por jueces profesionales, entre los cuales juristas de prestigio, continuadores de Homobonus, como Ponç Bonfill Marc y Vives, ambos clérigos ${ }^{90}$.

Estos jueces, asistidos por nobles y clérigos, administraron justicia en pleitos de los años 1025, 1028 y 1032-33, que enfrentaron a Sant Cugat con propietarios y señores de la Marca del Penedès por la posesión de tierras ${ }^{91}$. El más célebre de estos pleitos fue el que en los años 1032-33 enfrentó al monasterio con Mir Geribert por las tierras de Calders y Santa Oliva, y que era continuación de un pleito de 1013 y 1017 ya citado ${ }^{92}$. De esta causa existen en el CSCV cuatro instrumentos: una declaración jurada de tres testigos que decla-

${ }^{85} \operatorname{CSCV} 452$ y 464.

86 Preceptos de Carlos el Calvo y Luís de Ultramar, perdidos durante el asalto de al-Mansur (985), y renovados por Lotario (ABADal, Diplomes, págs. 190-200).

${ }^{87} \operatorname{CSCV} 470,496$ y 545.

88 CSCV 438,479 y 542.

${ }^{89}$ CSCV 512. Este juicio se resolvió favorablemente para Sant Cugat cuando el abad mostró su disposición a hacer intervenir el juez Bonfill Marc en el examen de las escrituras.

${ }_{90}$ Sobre Bonfill Marc, véase CSCV 437, 464, 470, 496, 497, 509, 512, 523, 524, 527 y 529, y Balari Jovany, José, Orígenes históricos de Cataluña, Sant Cugat del Vallés, 1964 (1.a ed. en 1899), págs. 471-480. Sobre Homobonus, que ya actua en juicios anteriores al año mil, CSCV 438, 452.

91 CSCV $497,509,523,524,527$ y 529.

32 CSCV 452 y 464. 
ran haber conocido el precepto del rey Luis, que fue destruido por la incursión de al-Mansur, y renovado por el rey Lotario, según el cual Sant Cugat posefa la tierra de Calders y Santa Oliva, y que ellos han sido testigos de esta posesión ininterrumpida durante sesenta años ${ }^{93}$; una segunda declaración jurada, ésta de seis testigos, que declaran haber presenciado y escuchado la declaración anterior y que está firmada por Mir Geribert, como tutor de su hijo (nieto del vicario Guillem de Santmartí), reservándose el plazo legal de seis meses para reprobar a los testigos, o aceptando, en su defecto, el derecho de Sant Cugat ${ }^{94}$, y dos noticias-resumen del pleito que contienen la sentencia y su confirmación ${ }^{95}$.

Según estos documentos ${ }^{96}$, Mir Geribert reivindicaba en nombre de su hijo las tierras de Calders que, según decía, había aprisionado su bisabuelo Galí de Santmartí. De éste, la propiedad había pasado a su hijo Guillem, pero a su muerte, su viuda Adelaida y sus herederos habian sido injustamente expulsados del lugar por el conde Ramon Borrell que lo entregó a Sant Cugat. A estas alegaciones el abad respondió argumentando que Sant Cugat poseía la tierra legítimamente por preceptos carolingios, bulas papales y documentos condales, y por el hecho de haber realizado obras de defensa y cultivo en la zona. Y apoyó estos argumentos con la presentación de escrituras. El tribunal las examinó atentamente, en particular el precepto del rey Lotario, pero dudó por el hecho de que el precepto originario, el del rey Luis hubiera sido destruido, por lo que pidió al abad la presentación de testigos que confirmaran su contenido y dió para ello ocho días de plazo. Dentro de los términos establecidos el prelado presentó tres testigos que, en base a su conocimiento del contenido del precepto perdido y de la posesión efectiva e ininterrumpida del territorio por Sant Cugat, ratificaron el derecho del monasterio. Estas declaraciones fueron efectuadas en la iglesia de Sant Pere cercana al cenobio Sant Cugat y en la iglesia Martorell, y ratificadas por testigos en la iglesia del castillo de Eramprunyà. Mir Geribert no aceptó lass declaraciones, abandonó la audiencia y después se presentó ante el juez Ponç Bonfill Marc, en Barcelona, para difamar a los testigos y así invalidar su testimonio ${ }^{97}$. El juez le pidió pruebas o testigos que sostuvieran tales acusaciones, y Mir Geribert, que prometió aportarlas, le pidió a su vez la apertura de diligencias para tomar declaración a testigos que declarasen a favor de la aprisión efectuada por Galí de Santmartí. El juez, después de mucha insistencia, accedió a ello, no sin antes recordarle que si no conseguía "difamar» a los testigos de Sant Cugat, las declaraciones de sus testigos no tendrían ningún valor frente al derecho

93 CSCV 523 (lleva la fecha de 28 de junio de 1032).

94 CSCV 524 (lleva la fecha 3 de jutio de 1032).

95 CSCV 527 y 529 (llevan la fecha de 18 de marzo y 30 de julio de 1033).

96 Intentamos aquí, a partir de estos documentos y de forma muy provisional, reconstruir el orden del proceso que, creemos, presenta algunos puntos oscuros en sus eslabones finales.

97 A uno que era clérigo le acusó de concubinaje y abandono de los hábitos; a otro, de adulterio, y a un tercero de apostasia. A partir de este punto, nuestra interpretación de las secuencias del proceso difjere de la presentada por BALAR1, op, cit.; págs. 407-414.

Hispania, LVIH/3, nu்m. 197 (1997) 1009-1048 
más antiguo y valioso del cenobio. Después, pasado cierto tiempo, el juez convocó a las partes a una audiencia en la iglesia de Cornellà para que el abad escuchara la "difamación" de sus testigos, pero Mir Geribert, que había recibido la convocatoria a las puertas de la catedral de Barcelona, ante el obispo y los barones, no se presentó. Finalmente, las partes convinieron en celebrar una audiencia en la iglesia de Santa Maria de Martorell, que debió ser la definitiva. Aquí, después de muchas disputas, el tribunal entendió que la verdad se inclinaba hacia la parte del cenobio, cuyo derecho, en base a sus escrituras y testigos, era más justo, verdadero y enterior al de los Santmartí. Por ello se consideró pertinente recibir las declaraciones de los testigos del abad y rechazar las de los testigos de Mir Geribert, que siguió sin aceptar las declaraciones de aquellos mientras gritaba que era víctima de un trato injusto. Finalmente, el tribunal sentenció en favor de Sant Cugat invocando para ello no menos de tres veces la Lex Visigothorum: primero, para decir que si una parte aporta testigos y la contraria no los puede «difamar» el pleito debe continuar en base a las declaraciones aportadas (II, 4, 8); segundo, que los bienes dados a las iglesias deben pertenecerles perpetuamente $(\mathrm{V}, 1,1)$, y tercero, que el que tiene un bien durante treinta años en paz no lo ha de perder $(X, 2,6)$.

Todo lo examinado hasta aquí conduce a afirmar que el proceso de tradición goda, impulsado por jueces expertos en la Lex, aún segúa vigente en el condado de Barcelona el tercer decenio del siglo XI. No obstante, bajo la capa formal de la continuidad aparecen los primeros cambios. Ciertamente, seguía en vigor la idea de que los preceptos carolingios eran un título jurídico valioso aunque, junto a ellos y como si empezaran a perder peso, los abades esgrimen también bulas papales y escritos condales. Entre las novedades a resaltar está lo que nos parecen indicios de una tendencia a resolver los pleitos mediante pactos, un proceder que todavía en estos años se produce en el marco de la propia administración de justicia o bien porque los tribunales aconsejan a las partes enfrentadas llegar a acuerdos ${ }^{98} \mathrm{o}$ bien porque el abad, ganador en el pleito, estima pertinente hacer determinadas concesiones a sus oponentes pro humanitatis misericordie o compunctus et misericordia motus ${ }^{99}$. Más importante aún debe ser el hecho de que hombres importantes como el vizconde Adalbert del Rosellón, en el 1025, y Mir Geribert, en el 1032-33, menosprecien la justicia cuando les es adversa, griten en plena audiencia, no quieran recibir los testimonios contrarios y abandonen la sala del juicio: el propio palacio condal de Barcelona en el primer caso ${ }^{100}$.

En el marco de estos primeros rechazos a las formas más tradicionales de justicia debemos señalar, como muy significativo, el comportamiento del noble Bernat Otger, que en 1047 compareció ante un tribunal presidido por la condesa Ermessenda y su hijo Ramon Berenguer I para disputar a Sant Cugat tierras de Santa Oliva, Calders y Castellet ${ }^{101}$. Escuchadas las alegaciones, el

$98 \operatorname{CsCV} 452$ y 479.

99 CSCV 438 y 542.

100 CSCV 496.

101 CSCV 545. 
tribunal pidió a ambas partes que aceptaran los mecanismos legales, dieran fiadores y se ofrecieran mutuas garantías de que permanecerían en juicio acatando la sentencia, según establece la Lex. Pero Bernat Otger rechazó someterse al yugo de la ley (Bernardus noluit se mittere sub iugo supradicte legis) y dijo que el único derecho que aceptaría sería el que determinara el juicio de Dios: mittamus, dijo, singulos puerulos ad iudicium Dei Omnipotentis in aqua frigida, ut inde appareat cuius directum sit. El tribunal se percató entonces de que no había otro modo de resolver el pleito, y aceptó la ordalía que no dió un resultado totalmente concluyente: el párvilo de Sant Cugat fue cubierto pero no retenido por el agua, y el de Bernat Otger se mantuvo en la superficie $^{102}$. El tribunal quiso entonces repartir a medias los bienes y derechos en disputa, pero las quejas de Bernat Otger y el deseo de evitar conflictos mayores llevaron a un acuerdo por el cual el noble obtendría la mayor parte y Sant Cugat la menor.

De nuevo, aquí, más que a un juicio creemos haber asistido a una prueba de fuerza, escenificada con mecanismos extralegales, y resuelta por pactos. $Y$ como señal de que así, casi imperceptiblemente, hemos entrado en una nueva época, unos años más tarde, en 1044, el abad pactó una convenientia con Bernat Otger, su oponente, por la que le entregaba su parte en feudo ${ }^{103}$. Lo sucedido es más que una anécdota. Por voluntad de un poderoso señor de la frontera, el tribunal condal acepta dejar de lado las normas procesales y admite una prueba irracional o aberrante (desde nuestro punto de vista), que ya entonces debía formar parte de un conjunto de prácticas paralelas a la justicia ordinaria. La novedad es que un tribunal, integrado por condes, obispos, magnates, clérigos y jueces, rompe la tradición y acepta esta ordalía ${ }^{104}$. No menos importante es reflexionar sobre lo que significa la actuación de Bernat Otger, situada en el marco de los desplantes del vizconde Adalbert y de Mir Geribert a la justicia y de la tendencia insinuada a resolver los pleitos mediante pactos. Todo esto significa que la justicia tradicional, muy unida a la Iglesia (seguramente demasiado) y vinculada a procesos regulares, normas escritas, pruebas objetivas y expertos, a pesar de ser, como decíamos, una justicia de clase (de la clase aristocrática), imponía a las ambiciones de poder y riqueza de la aristocracia laica unos límites que ésta ya no quiere tolerar. En resumen, Bernat Otger está convencido de perder el pleito si sigue las pautas de un proceso regular y por ello rompe la baraja e impone un cambio en las reglas de juego.

No es un caso aislado. Otros documentos de mediados de siglo se situan en la misma linea. Claro que una vez más debemos distinguir entre conflic-

\footnotetext{
102 Las bases de la prueba eran que el derecho seria de la parte cuyo puerulus (párvulo) fuera recibido por el agua, pero, en el caso de que ambos párvulos fueran recibidos o rechazados, el derecho correspondería a ambas partes, con lo que se impondría un reparto del bien en disputa.

103 CSCV 571.

104 Aunque la ordalía del agua hirviente estaba contemplada por la Lex, quizá por una interpolación tardía, la ordalia que propone Bernat Otger no se encuentra en la Lex (BALARI, op. cit., págs. 419-420).

Hispania, LVII/3, núm. 197 (1997) 1009-1048
} 
tos horizontales y verticales. Éstos, mucho menos documentados que aquellos, siguen todavía la mecánica tradicional: tribunal de nobles, jueces, clérigos y hombres buenos; alegaciones del abad y los acusados; lectura de escrituras; declaración de testigos; examen de lindes; plazos para "difamar" testigos o aportarlos más y mejores, y sentencia y exvacuación ${ }^{105}$. En cambio, la resolución de pleitos entre poderosos se orienta definitivamente hacia la negociación, lo cual tiene cierta lógica: al inferior se le impone la justicia; con el poderoso se pacta. Así, por pacto o convenientia, se resolvió un conflicto entre Sant Cugat y sus feudatarios del castillo de Clariana, en $1058^{106}$. Por este documento sabemos que el monasterio y los castellanos de Clariana habían hecho un primer acuerdo por el cual esta familia noble tenía Clariana como feudo del abad, quien retenía allí una dominicatura o reserva, el presbiteratum y un tercio de los diezmos, de los ingresos de la justicia y de las herencias. Al parecer, con el paso de los años, los Clariana incumplieron el acuerdo y usurparon derechos del monasterio por lo que fueron acusados ante la corte de Ramon Berenguer I y Almodis. El examen de la cuestión y las informaciones de testigos convencieron a la audiencia de las razones del abad, pero recomendaron una renovación de la convenientia, como así se hizo.

Es interesante observar que la autoridad condal, rodeada de los próceres de la corte, ahora prefiere el pacto a la sentencia o modera la una con lo otro. Pero el documento interesa más aún porque muestra una nueva faceta de la justicia en pleno siglo xI: la ruptura jurisdiccional. En efecto, el abad, que desde la época carolingia, tiene por concesión regia (preceptos de inmunidad) la potestad de administrar justicia a los campesinos de sus dominios, comparte ahora esta función con castellanos afincados en sus tierras. Parece más una situación de hecho (de fuerza) que de derecho. Y la administración de justicia, que años antes todavía podía presentarse como un servicio público, tiene así más claramente tintes señoriales. Es como si se hubiera pasado de una justicia pública, con contenido de clase, a una justicia personal, más fácilmente abusiva: al respecto, el abad tiene buen cuidado en la convenientia de establecer que sus bailes y agentes en Clariana no serán sometidos al tribunal del castellano, ni sufrirán por su causa violencia alguna. Añadir entonces que la administración de justicia ha pasado de ser un servicio público a ser una forma de obtención de ingresos para la aristocracia es casi una obviedad. Ahí está para corroborarlo este reparto pactado de los placitos entre abad y feudatario, como se reparten diezmos y derechos sobre herencias. Y no es caso singular: en archivos y cartularios catalanes se encuentran centenares de convenientiae y de inventarios que ilustran esta ruptura jurisdiccional y el consiguiente reparto de los ingresos de la justicia, junto con las restantes rentas feudales.

Ios Esto es, por ejemplo, lo que sucede con un pleito sobre la propiedad de unas viñas de Gualba (Vallès Oriental) en 1045 (CSCV 577).

IOK CSCV 612. 
Si comparamos lo observado en el CSCV con la documentación de la sede de Gerona del CC observamos un estrecho paralelismo. Hasta mediados del siglo XI seguimos encontrando actas de juicios; algunas incluso muestran con todo lujo de detalles, la mecánica del pleito en la más pura tradición procesal hispanogoda. En todos estos juicios ${ }^{107}$, jueces profesionales (Sunifred, Guillem, Ponç Bonfill Marc), rodeados de nobles, clérigos y hombres buenos, llevan el peso del proceso, que en tres ocasiones fue presidido por el conde Bernat de Besalú: en 1003, cuando se presentó en su corte y castillo de Besalú el obispo de Gerona para reclamarle las iglesias de Montagut y Beuda, y el conde, previa investigación, aceptó el mejor derecho de la sede Gerundense, en 1018 cuando la condesa de Barcelona y el conde de Ampurias pleitearon por el alodio de Ullastret ${ }^{108}$ y en 1019, cuando dos mandatarios del obispo de Gerona acusaron a Bernat de Calabuig de usurpar (mala presumptione) derechos de la sede en la villa de Bàscara, a lo que el acusado respondió que los bienes en disputa eran de origen familiar y estaban dentro de los términos de Calabuig y no de Báscara ${ }^{109}$. Como en el siglo IX, la presentación de preceptos carolingios, el recorrido por los términos de estas villas y la deposición de testigos bastó para que el tribunal se pronunciara a favor de la sede, aunque Bernat de Calabuig fue renuente a aceptar los juramentos de los testigos y abandonó la audiencia. Es la misma actitud de rechazo a la justicia condal y eclesiástica que hemos observado en pleitos barceloneses de esta misma época, y siempre protagonizada por poderosos.

El juicio más célebre de esta época, auténtico monumento a la pervivencia de la ley goda en Cataluña, fue el que enfrentó, en 1018, a la condesa Ermessenda de Barcelona, tutora de su hijo Ramon Berenguer I, y al conde Hug de Ampurias por la posesión del alodio de Ullastret. A tenor de la notitia iuditii, Hug reclamaba a Ermessenda el alodio porque, según decía, lo había vendido al conde Ramon Borrell, difunto, esposo de Ermessenda, in minoribus annis. Y añadía que la carta de venta se había redactado en presencia del conde Bernat de Besalú y del obispo Oliba de Vic. Con esta alegación, sin duda, Hug pretendía invalidar la escritura de venta, puesto que, según la Lex, los que se encuentran en minoría de edad, hasta que no hayan cumplido los catorce años, no pueden disponer libremente de sus bienes ${ }^{110}$. Ermessenda, que tenía documentos de Hug ya mayor de edad que ratificaban la transacción (legales definitiones seu sacramentorum colligationes), respondió aceptando llevar la causa a juicio ordinario, para lo que propuso dar fiadores y obligarse legalmente a seguir el proceso. Pero Hug rechazó la mecánica del pleito tradicional y propuso un duelo judicial (facere bellum) entre dos caballeros, uno por cada bando. El derecho sería del vencedor. Aunque el duelo judicial era prác-

$107 \operatorname{CC} 71,77,78$ y 100.

$108 \mathrm{CC} 77$.

109 CC 71 y 78 .

110 In minoribus annis constitutis testandi de rebus suis vel alias quascumque definitiones faciendi seu per scripturam sive per idoneum testem, in quibuscumque personis elegerint, infraquartum decimum annum non illis aliter licentia erit (Lex Visigothorum II, 5, 11).

Hispania, LVII/3, nu்m. 197 (1997) 1009-1048 
tica conocida en los círculos condales 111 , Ermessenda rechazó la propuesta con el argumento de que la lex gotica no obliga a dirimir los pleitos por la lucha (pugnam). Entonces Hug, sin base legal alguna (auctoritate legis gotice), y aprovechando la ausencia de la condesa Ermessenda, ocuṕ el alodio de Ullastret por la fuerza (invasio). Pronto la tensión generada, y seguramente el temor a males mayores, llevó a las partes y a sus amigos a buscar una salida legal al contencioso. Se reunió entonces un tribunal, formado por el conde de Besalú, el obispo de Vic, tres jueces (Guillem de Gerona, Guifré de Ausona y Ponç Bonfill Marc de Barcelona) y muchos nobles, ante el que Ermessenda presentó su reclamación, a la que el mandatario de Hug respondió que Ullastret no había sido «invadido» por el conde de Ampurias, porque estaba dentro de su condado y aquí la potestad había pasado del rey al conde: potestatem quam reges ibi pridem habuerunt, iste Ugo comes ibi habebat. Escuchadas las alegaciones, los jueces encontraron que, desde el día en que el alodio paś a manos de Ramon Borrell, éste lo tuvo sin impedimento alguno, y en él ejerció toda la potestad que antaño habían ejercido los monarcas carolingios, cobró impuestos e ingresos de la justicia y tuvo alli un juez y un sayón. Y que de él había pasado a su viuda Ermessenda hasta que Hug injustamente lo invadió. Por ello, abiertos los códices de la ley goda (apertis codicibus legum gotorum), sentenciaron a favor de la condessa. Pero el conde Bernat de Besalú, que secundaba a Hug, no aceptó la sentencia y, con maniobras procesales, forzó la reanudación del juicio. Entonces Ermessenda presentó testigos, que el mandatario de Hug no aceptó, al tiempo que abandonaba la audiencia sin permiso de los jueces. Éstos, según las leyes, tomaron declaración a los testigos quienes confirmaron la posesión del alodio por el conde Ramon Borrell y Ermessenda, hasta la usurpación del conde de Ampurias. Finalmente, escuchadas y juradas las declaraciones, los jueces dictaron una extensa sentencia a favor de la condesa, que arroparon con cuatro citas, largas y precisas, de la Lex: 1/ La ley V, 6, 6, sobre la iniquidad de levantar acusaciones contra personas difuntas en perjuicio de su descendencia (en respuesta a la acusación de Hug de que Ramon Borrell le había comprado indebidamente Ullastret); 2/ la ley V, 4, 20, sobre la ilegalidad de ejercer acciones jurídicas (ventas, donaciones) con un bien que está o debe estar sub iudice, y la necesidad, al respecto, de atenerse a la decisión de los jueces; 3 / la ley VIII, 1, 5, sobre la necesidad de devolver e indemnizar al propietario cuyo bien en litigio ha sido invadido o usurpado por la parte contraria sin esperar al dictado de los jueces, y $4 /$ la ley VIII, 1, 7, sobre la prohibición de inquietar los bienes de los ausentes.

Como decíamos antes, es probable que entre la documentación generada por los procesos en Cataluña no encontremos un testimonio mejor de la pervivencia de la Lex. En todo caso es un shomenajen tardío, testimonio a la vez de la continuidad y la crisis de la justicia hispanogoda tradicional.

111 Así se resolvió en 820 la acusación de traición lanzada ante la corte de Luis el Piađoso por un noble godo de la Marca contra el conde de Barcelona Berá, descendiente del conde franco Guillermo de Tolosa y de una mujer de la nobleza goda. Aquilino Iglesia (op. cit.) piensa, no obstante, que el duelo judicial era una práctica de los francos, desconocida entre los godos. 


\section{EL PACTO COMO JUSTICIA}

La documentación del CSCV de la segunda mitad del siglo XI y del XII es fiel expresión de los cambios. Retroceden las formalidades y avanza el pragmatismo. Ahora ya no interesa tanto el escrupuloso respeto a la norma procesal y sí en cambio el resultado del litigio. Por ello casi desaparecen del cartulario las actas o noticias-resumen de los pleitos, y proliferan las definitiones et evacuationes y las convenientiae ${ }^{112}$. Pero los acuerdos se hacen y deshacen con facilidad, y los pleitos se alargan y, cuando parecen resueltos, resurgen. En resumen, la conflictividad aumenta, lo cual está en consonancia con la situación revelada por otras fuentes, particularmente actas de asambleas de paz y tregua, y querimoniae, clamores y rancuras (inventarios de malefactas), relativas a lugares muy distintos de la Cataluna Vieja ${ }^{113}$.

Los abades de Sant Cugat tuvieron entonces multas contentiones, altercationes et placita con gente muy diversa, pero en el cartulario casi sólo ha quedado el recuerdo de los importantes: nobleza castral independiente, feudatarios castallanos de Sant Cugat, caballeros que poseían algunas domus o quadras por el monasterio y agentes señoriales (bailes o equivalente) ${ }^{114}$. Unos, desde fuera de los dominios monacales, y otros, desde dentro, se lanzaban sobre los bienes y riquezas de los tenentes del monasterio y de los propios monjes. Se disputaba por todo: medios e instrumentos de producción (tierras, prados, viñas, molinos); rentas, cargas banales y exacciones; centros de poder señorial (torres, castillos, bailías y cuadras); grandes explotaciones (dominicaturas o reservas); pequeñas explotaciones (mansos); deberes vasalláticos, etc. Algunos conflictos, sobre todo los concernientes a la posesión de tierras, son conflictos de viejo tipo, pero los restantes son nuevos. Nos referimos a las disputas por el cumplimiento de deberes vasalláticos, por la pose-

112 El cambio documental que entraña el predominio de las definitiones como testimonio único de los pleitos no es propio y exclusivo del CSCV, también se da en otras fuentes, como, por ejemplo, los documentos inéditos de la colegiata de Vilabertran conservados en la Biblioteca de Cataluña (GISPERT, Joan, Conflictes $i$ resolucions judicials en la gestió del domini de la canònica de Santa Maria de Vilabertran. Segle XI, Barcelona-Universidad Pompeu Fabra, 1996. Trabajo inédito de segundo curso de doctorado).

113 Gonzalvo, Genet, La pau $i$ treva a Catalunya. Origen de les Corts catalanes, Barcelona 1986; GaRí, Blanca, «Las "querimoniae" feudales en la documentación catalana del siglo X11 (11311178)", Medievalia, 5, 1984, págs. 7-49; Bisson, Thomas, "The crisis of the Catalonian franchises (1150-1200)», Estudi General, 5-6, Gerona 1985-86, págs. 153-172; SALRACH, Josep M., «Agressions senyorials i resistències pageses en el procés de feudalització (segles [X-XII)», en Revolles populars contra el poder de l'Estat, Barcelona 1992, págs. 11-29. FARíAs, Víctor, "Una "querimonia" desconeguda procedent de l'antic arxiu de Sant Cugat del Vallès», Gausac, 5, 1994, págs. 99-104.

114 En lo tocante al período $1050-1200$ nos basamos en nuestro estudio «Multa placita et contenciones: conflictos de los siglos X-XII en el Cartulario de Sant Cugat del Vallès» presentado al Colloque International Les origines de la Féodalité, Maison des Pays Ibériques, Talence, 22-23 octobre 1993 (en prensa).

Hispania, LVI1/3, núm. 197 (1997) 1009-1048 
sión de centros de poder señorial, por los mansos (palabra casi desconocida antes del siglo xI) y directamente por la sustracción. La impresión es que en esta nueva fase los poderosos ya no luchan tanto por la tierra como por el excedente: el fruto del trabajo o las formas coercitivas necesarias para obtenerlo. De un modo muy concreto, los conflictos por la confiscación del excedente son disputas por la sustracción salvaje (toltas, forcias), las albergas, los tributos eclesiásticos, las rentas agrarias y las tasas de mutación. Ni que decir tiene que esta lucha entraña acciones de fuerza y violencia (predas, malas prisiones, forfeturas, malefactas, magnas iniurias) que se ejercen directamente sobre el campesinado, en un «juego" de presiones y reacciones, que ya es genuinamente feudal is

Este «juego" se «juega» a partir de torres y castillos en los propios campos, donde a veces adquiere los tintes de guerra feudal, como no dejan de recordar las convenientiae y los juramentos de fidelidad: nullus ex eis de predicto castro guerram non concitet o aliquod malum non exeat de domo vel fortitudine ${ }^{116}$. Al final la última partida de este "juegon (aunque súltima” es mucho decir en querellas de feudales) se juega a veces ante los tribunales. ¿Qué tribunales? A partir del 1058 y hasta finales del siglo XII, con una sola excepción ${ }^{17}$, los condes no presiden ningún pleito de los contenidos en el CSCV. La mayor parte fueron conflictos dirimidos por audiencias o más bien asambleas integradas únicamente por hombres buenos (probi homines, nobiles homines), generalmente miembros de la nobleza y eclesiásticos (abades, priores, sacerdotes, monjes) ${ }^{118}$. En segundo lugar hubo audiencias presididas por autoridades religiosas como el arzobispo de Tarragona (en 1131, 1135, 1150, 1180, 1183 y 1191 ), el obispo de Barcelona (en 1114, 1159, 1181 y 1185) y abades y arcedianos ${ }^{119}$. Y en último lugar hay unas pocas audiencias presididas por uno o varios jueces (acompañados o acompañando a veces a prelados), que en el caso del juez Borrell de Gerona, en juicios de los años 1160-63, en época de Ramon Berenguer IV, parece ser un hombre de la confianza del conde por

115 Naturalmente, en el CSCV, a pesar de la naturaleza más bien administrativa de la documentación, abades y monjes hablan đe lo que más les duele (los problemas de su hacienda), pero son suficientemente explícitos para dejar entrever también que, al fin y al cabo, a quien más duelen las disputas «señoriales» es a los campesinos. Como ejemplo puede leerse la querimonia publicada por Farias, op. cit.

116 CSCV 612 y 1042.

117 Nos referimos a un juicio de 1160 presidido por Ramon Berenguer IV, acompañado de los obispos de Barcelona y Zaragoza, y de magnates de la corte (CSCV 1.031).

$118 \operatorname{CSCV} 624,625,626,677,776,783,812,852,885,862,864,873,895,913,920,934,947$, $953,982,986,989$ (es de 1153 e interviene un baile condal), 993, 997, 1.004, 1.024, 1.025, 1.032, $1.058,1.062,1.073,1.079,1.084,1.087,1.097,1.107,1.108,1.113,1.115,1.116,1.127,1.134$, $1.146,1.161$ y 1.183 .

$119 \operatorname{CSCV} 822,909,930,984,1.027,1.055,1.130,1.133,1.147,1.148,1.156,1.185$ y 1.212. En un juicio de 1180 (doc. 1.130), en plenz fase de recuperación de la autoridad condal-real, integran el tribunal el arzobispo de Tarragona, el juez de palacio Miró y un conjunto de magnates, de los que se dice ex mandato domini regis fuerunt assessores et iudices. 
cuya autoridad ejerce, y una audiencia de 1181 presidida por el veguer de Barcelona ${ }^{120}$.

De la lectura de los documentos se deduce que durante algo más de un siglo (de mediados del siglo XI a mediados del siglo XII al menos) la justicia no dependió de la autoriad condal y su tribunal. En detrimento de la justicia ordinaria, las partes en conflicto se pusieron entonces de acuerdo muchas veces para dirimir sus diferencias ante una asamblea de amigos o un grupo reducido de hombres de prestigio que les ayudaran a buscar un compromiso o arbitraran sus diferencias con un laudo. Con todo, algunos elementos del proceso penal tradicional siguieron utilizándose. Al comparecer, las partes, una vez elegidos los jueces, eran requeridas a aceptar la jurisdicción de la asamblea o tribunal, someterse a sus requerimientos y aceptar su veredicto, lo que se expresaba con la formula tradicional: firmare directum o firmare iure. Como garantía de ello entregaban prendas (pignoras) o presentaban fiadores (fideiussores) ${ }^{121}$. Estos tribunales siguieron requiriendo pruebas escritas y testigos orales. La novedad fue que las causas más genuinamente feudales entrañaban un gran número de sustracciones, infracciones y violencias, que había que exponer y evaluar, lo cual aconsejaba que cada parte compareciera con sus inventarios de quejas (las querimoniae) para mejor exponerlas al tribunal. La documentación del CSCV contiene numerosas referencias a estas querimoniae, de las que no obstante han quedado muy pocos ejemplares, puesto que, como vemos, no tenían valor probatorio y su función era meramente coyuntural.

El cambio más significativo en la mecánica del pleito entre poderosos, por comparación al período anterior al año mil, aparece en el punto final del proceso donde observamos que muy pocos tribunales dictan sentencias firmes a la vieja usanza, es decir, completamente favorables a una parte y desfavorables a la contraria. Disponemos para afirmarlo casi únicamente de definitiones et evacuationes, es decir de declaraciones de una parte reconociendo la injusticia de sus pretensiones y aceptando el mejor derecho de la parte contraria. Si se quiere hasta aquí no hay nada nuevo: este tipo de documentos también proceden de la tradición. La novedad es que los pacificatores ac definitores et evacuatores ${ }^{122}$ dicen no actuar por sentencia judicial sino por laudo, consejo, persuasión, negociación y compromiso: dixerunt atque laudaverunt, non iudicio sed laudamento, non directo sed consilio, laude et consilio proborum hominum ${ }^{123}$. Pero lo más novedoso es observar que en la mayoría de los

$120 \operatorname{CSCV} 725,822,869,875,1.035,1.036,1.050$ y 1.137.

121 Conviene advertir que este proceder ya era contemplado por la Lex Visigothorum donde se dice que nadie tiene potestad de juzgar salvo quien ta ha recibido del príncipe o el que la tiene por elección de las partes en conflicto: Dirimere causas nulli licebit, nisi aut a principibus potestate concessa, aut ex consensu partium electo iudice (II, 1, 15). A la misma posibilidad de elección del juez por la partes se refiere también la ley II, 1, 27.

122 CSCV 725.

123 CSCV 1.050.

Hispania, LVI/3, múm. 197 (1997) 1009-1048 
casos a este desenlace se ha llegado a través de una negociación ${ }^{124}$ en la cual el monasterio obtiene el reconocimiento de sus derechos y la parte contraria es resarcida con dinero. Así terminan más del $60 \%$ de los litigios de Sant Cugat y también la casi totalidad de los de la canonica de Vilabertran en la misma época ${ }^{125}$. En el fondo la misión del tribunal, y de ahí la función de las querimoniae donde las violencias aparecen tarifadas, no es otro que encontrar un precio aceptable por las partes para dar fin al litigio. Se podría decir, por tanto, que la justicia del primer feudalismo era una justicia venal, en el sentido de que el precio del acuerdo ocupaba el lugar de la sentencia.

Otras veces, especialmente cuando el conflicto era entre señor y vasallo, se resolvía, a través del consejo de los amigos del tribunal o asamblea, con la negociación o renegociación del pacto feudal (convenientia), precedida de un acto de contrición: tandem veni ad placitum ubi consilio meorum amicortum ac seniorum recognovi quia iniuste faciebam, ad finem et concordiam devenio, venerunt ad finem et transactionem ${ }^{126}$.

Como sucede con la documentación del CSCV, en la del CC también desaparecen las actas-resumen de los pleitos a mediados del siglo XI y no reaparecen hasta finales del siglo XII. Para conocer la mecánica del pleito en esta fuente no disponemos más que de 57 definitiones ${ }^{127}$, tres documentos de concordia, uno de arbitraje (ya de 1179) y una notitia de un juicio de 1180 o $1181^{128}$. También, como sucedía con las definitiones del CSCV y de los per-

124 Entiéndase bien: novedoso hasta cierto punto. La legislación visigoda ya contemplaba que los litigios pudieran resolverse por acuerdo (convenientiae dice la $L e x$ ) entre las partes, al margen de\} procedimiento judicial ordinario, es decir, ante el tribunal del principe o de sus jueces. Lo que la Lex no aceptaba era que una causa, llevada ante la justicia ordinaria, pudiera después resolverse entre las partes al margen del juez responsable del proceso. Lo pertinente era que las partes esperaran la sentencia del juez o, en su defecto, el permiso de éste para negociar. Pero lo normal y deseable, según la ley, era que los pleitos llevados ante la justicia ordinaria terminaran con una sentencia, porque esta era la mejor forma de garantizar el fin de los conflictos: Si cepta causantium negotia dirimentis non terminet discreta censura, non solum difficile sedantur altercantium negotia, sed et diversis causatur obiectionibus iustitia perquisita (Lex Visigothorum II, 2, 10). Pues bien, to que sucede ahora, en plena época feudal, es una total inversión de la Lex: 1/ las causas no se llevan ante la justicia ordinaria, sino ante asambleas de barones o jueces arbitrales escogidos por las partes; $2 /$ los jueces, más que dictar sentencia, aconsejan la mejor forma de negociar una salida al conflicto, o cuando dictan un laudo es porque lo han consensuado entre la partes, y $3 /$ el final del litigio, aunque muchas veces se presente formalmente como una definitio, es en realidad una compra-venta de derechos. Tanto es así que al final la palabra definitio adquirirá valor polisérmico: un estudio sistemático de los pergaminos de Vilabertran y de las escrituras del $\mathrm{CC}$ revela que un cierto número de definitiones de los siglos XI y XII son ya simples escrituras de venta de tierras e incluso de redención de servidumbres.

125 GISPERT, op. cit.

$126 \operatorname{CSCV} 864,947,1.107$ y 1.108 .

127 Mejor deberiamos decir 46 porque hay 11 definitiones que en realidad son escrituras de venta o liberación de derechos, entre las cuales seis ventas de siervos, es decir, hombres con su cuerpo, bienes y descendencia, efectuadas a favor de terceros o de los propios siervos. Se trata de escrituras de 1100-1197 (CC 182, 241, 306, 311, 321, 323, 331, 349, 361, 364 y 372).

${ }_{128}$ CC $249,334,335,343$ y 362. 
gaminos de la canónica de Vilabertran, entre 1100 y 1153 casi todas las definitiones del $\mathrm{CC}$, originadas por conflictos, aunque favorezcan a la Iglesia gerundense, entrañan algún tipo de compensación económica para los definitores ${ }^{129}$.

Este pago corrobora la idea de que, a diferencia de la época prefeudal, la solución de los conflictos durante el primer feudalismo se alcanzaba más por negociación y pacto que por sentencia ajustada a derecho. Para comprender las causas de este proceder hay que pensar en una diseminación del poder y diferenciar una vez más entre la justicia aplicada a hombres y familias de las clases inferiores, que no aparecen en las fuentes aquí examinadas ${ }^{130}$, y los mecanismos utilizados para juzgar a los potentes o resolver sus conflictos internos. Como ya sucedía en el CSCV, en el CC sólo encontramos noticias de estos litigios, y aquí en concreto, de los que se resolvieron de un modo favorable a Iglesia de Gerona (obispo, capítulo e iglesias locales). En la nómina de los definitores, es decir, de los oponentes uarrepentidos" de la sede figuran la mayor parte de las familias de la aristocracia gerundense, empezando por los propios condes de Besalú 131, y siguiendo por los señores de Navata, Torroella de Montgrí, Mata, Fonolleres, Cartellà, Rabós, Cruïlles, Peratallada, Palol, Anglés, Finestres, Calabuig, Cistella, Llers, Rocacorba, Palera, Maçanet, Catllar, Sales y Cervera ${ }^{132}$. Estos guerreros utilizaban las fortalezas como puntos de apoyo para sus correrías y saqueos por los campos, mansos y villas de la Iglesia de Gerona y de sus clérigos: de ipsa forteza que est vel erit in Torrocella de Montegrinio vel in eius terminis dampnum vel malefactum non venient ad te vel ad sedem Sancte Marie Gerundensis nec ad honorem eiusdem sedis le promete el castellano de Torroella al obispo después de una agria disputa ${ }^{133}$.

Como también sucedía en el dominio de Sant Cugat, las causas de los conflictos entre la Iglesia de Gerona y la nobleza eran más por la sustracción y las formas de violencia o coerción para obtenerla que por la tierra, aunque tampoco faltan las disputas por alodios, sacrarias, tierras, mansos, etc. Más frecuente, no obstante, era la disputa por cargas banales antes desconocidas, como las acaptas, toltas, forcias, receptos, usaticos y malos usaticos, a menudo

129 CC $186,189-90,223,236,242,264,265,266,271,274,276,280,281,284$ y 290.

t30 Debían comparecer ante la justicia señorial ejercida por agentes de los señoríos (los bailes) reforzados por guetreros de las guarniciones castrales. Hay indicios, en el siglo XII, de tensiones entre la monarquia y la nobleza por la negativa de ésta a aceptar que los campesinos de sus setiorios pudieran acogerse a la justicia real. El desenlace de esta pugna debió ser la constitución de las Cortes de Cervera de 1202, que legalizaba el derecho de los señores a maltratar impunemente a sus campesinos (MARCA, op. cit., ap. 493, col. 1.394). Durante los siglos XI-Xill, la violencia senorial pudo empujar a familias campesinas a abandonar sus tierras para refugiarse en señoríos más benignos. Quien sabe si la competencia jurisdiccional que entonces debió desatarse no fue la causa directa de las servidumbres reales y personales, es decir, del control sobre la residencia, movilidad, matrimonio y sucesión de los campesinos.

131 CC 116,135 y 136.

132 CC 138-139, 145-146, 223, 228, 235, 236, 257, 264, 265, 270, 277, 281, 284, 294, 296, 297, $298,305,307,309,324,332,348,360,365$ y 367 .

$133 \mathrm{CC} 145$.

Hispaniá, LVII/3, núm. 197 (1997) 1009-1048 
mezclados con albergas abusivas ${ }^{134}$, aunque muchos documentos no se entretienen en los términos de esta piratería señorial y prefieren descaradamente fórmulas genéricas pero muy expresivas del tipo de «los frutos saqueados» (direptis fructibus), "la rapiña» (per rapinam, rapuerunt), «las exacciones injustas, jlícitas y violentas" (exactiones...modo iniuste, exactionem vel violentiam, exactiones licitas vel illicitas sive rapinas et malas presumptiones) y «capturas y expolios" (perprisiones et spolia) ${ }^{135}$. También se litigaba por cargas tradicionales, rentas de la tierra (censos y tascas sobre todo), derechos de justicia y servicios ${ }^{136}$. Lo más interesante en esta fuente es la pugna por el control de las iglesias entre la sede gerundense y la nobleza local, lo cual quiere decir lucha por los bienes territoriales de los templos, pero sobre todo por los tributos eclesiásticos, especialmente los diezmos, cuyo alcance se define: tam de agris ac vineis et omni laboratione quam de molendinis, columbariis, ortos, lana, lino, canabo et universis que decimari possunt ${ }^{137}$. En el CC la primera definitio de una iglesia con sus derechos es la de Navata, efectuada en 1099, por Bernat Adalbert de Navata en favor de su hermano, clérigo de Gerona ${ }^{138}$. Es como si, de momento, el conflicto por las iglesias todavía no hubiera estallado: el problema se arregla en familia. Pero poco después, dentro de la primera mitad del siglo $\mathrm{x} \Pi$, aparecen los indicios de una política episcopal tendente a conseguir el control de los bienes y derechos de las iglesias. Para obtenerlo el prelado usa de las sanciones canónicas (anatema contra la iglesia de Borgonyà) pero también está dispuesto a negociar y pagar ${ }^{139}$. A mediados de siglo la ofensiva episcopal debió recrudecerse contra los señores que se atribuían derechos jurisdiccionales (vicaria) sobre las iglesias de sus señoríos o próximas a ellos. El resultado fue una seria de definiciones que afectaron a más de una docena de iglesias, y por las que aparentemente la sede no pagó cantidad alguna ${ }^{140}$. Todo induce a creer que para actuar así el prelado gerundense contaba con el respaldo del conde de Barcelona Ramon Berenguer IV. En efecto, en 1159 este gobernante definió, en provecho de la sede gerundense y de su obispo, todas las iglesias y capellanías que el obispo reclamaba, y que injustamente - dice el texto- eran poseidas por caballeros vasallos del conde, de modo que ninguno de ellos pudiera ejercer en el futuro ullam dominationem sive exactionem vel violentiam en ellas ${ }^{141}$. Después de esto, durante toda la segunda mitad del siglo XII, se multiplicaron las definiciones concernientes a iglesias (diezmos, primicias y dominaciones, excciones y vicarías de iglesias) ${ }^{142}$. Aparentemente los nobles las cedieron sin compensación, pero no

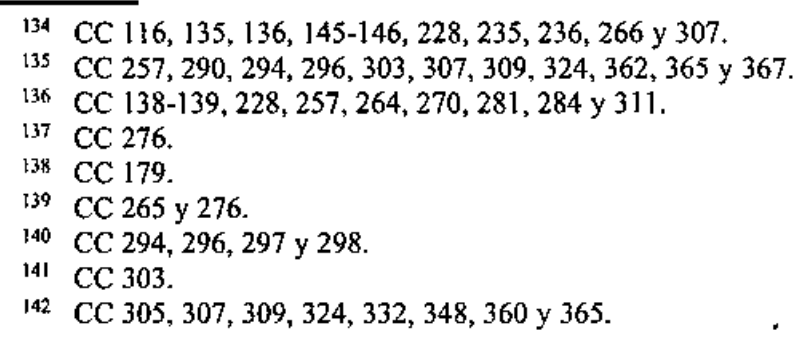


de buen grado: a menudo recuerdan que los derechos y exacciones que renuncian eran de sus antepasados, y en algún caso fue menester la excomunión para reblandecerlos ${ }^{143}$.

En cuanto a los mecanismos por los cuales las partes enfrentadas llegaban a una solución final, como la renuncia, pagada o no, de una de las partes, el reparto del bien en disputa o la redefinición de sus relaciones anteriores, el $\mathrm{CC}$ contiene escasa información pero en todo coincidente con el CSCV. Observamos ante todo la mediación, en los litigios, de amigos comunes que actuaban como amigables componedores o como árbitros que daban laudos o consejos (consilio et laudamento), lo cual generalmente conducía a soluciones de compromiso (ad bonum finem et amicabilem transactionem sive compositionem) consistentes en el reparto de las riquezas o derechos disputados o la modificación de la condiciones de tenencia: controversias de 1129 (con los señores de Sales), 1178 (con un baile), 1179 (un tenente importante) y 1190 (con el castellano de Torroella) ${ }^{144}$.

Como resumen de lo observado hasta aquí, podríamos decir que tanto en Sant Cugat como en Gerona, la aristocracia laica y eclesiástica lucha por el excedente del trabajo campesino. Al ritmo de los cambios económicos y de la oxidación de las antiguas formas de explotación, el consenso tradicional sobre el reparto de la riqueza entre poderosos y sobre los mecanismos para sustraerla se han roto. Y, en esta nueva lucha de poder a poder, poco puede hacer la justicia tradicional si no es respetada (consenso social) y no cuenta con una autoridad fuerte que la respalde. Respeto por la justicia tradicional, evidentemente no había cuando los poderosos se burlaban de ella, abandonaban las audiencias o proponían cambiar las pruebas "objetivas" por pruebas de fuerza. Lo dećamos páginas atrás, en esta fase histórica, la justicia, antes útil para reproducir las condiciones de explotación, ahora, cuando conviene imponer nuevas formas de explotación o maximalizar las antiguas, más bien debía ser un estorbo. No hay tampoco autoridad fuerte, garante del derecho y de la justicia, cuando los condes dejan de presidir las audiencias y los hombres que actuan al frente de ellas no dicen proceder en su nombre. En estas condiciones, cuando los poderosos que luchan por el poder y la riqueza no alcanzan a dirimir sus diferencias por las armas y no confían en la justicia o no pueden confiar en ella porque la han destruido ¿qué les queda sino negociar y pactar?

Hasta podría resultar reconfortante imaginar esta evolución, desde la violencia imperativa de la justicia pública con contenido de clase (la fuerza brutal del Estado antiguo y sus sucedáneos altomedievales), hasta la justicia pactada del primer feudalísmo, sino fuera ingenuo o mendaz olvidar que de pacto sólo lo había entre poderosos: a las clases populares del feudalismo

143 CC 324,360 y 365 . Las razones de la nobleza en sus conflictos con la lglesia han sido muy bien expuestas por Weinberger, Stéphen, «Les conflits entre clercs et laics dans la Provence du $\mathrm{xl}^{\mathrm{s}}$ siècle), Annales du Midi, 92, 1980, págs. 269-279.

${ }_{144}$ CC $249,334,335$, y 362.

Hispania, LVII/3, nủm. 197 (1997) 1009-1048 
se les imponfa la justicia señorial, que ahora quiere decir personal y sin límites ${ }^{145}$

\section{La Restauractón del PROCESO}

La segunda mitad del siglo XII la autoridad de los condes de Barcelona parece afianzarse. Puede ser el resultado natural de sus éxitos políticos y militares. Podríamos decir también que es una consecuencia de la resaca de las violencias anteriores, cuando los feudales buscan consolidar posiciones y reproducirse creando el Estado feudal o monarquía feudal, lo cual quiere decir admitir sino propiciar una cierta recuperación (en buena medida fracasada) del control central del orden público, el derecho y la justicia: recordemos la compilación de los Usatges de Barcelona efectuada en tiempos de Ramon Berenguer III, como cree Joan Bastardas ${ }^{346}$. En parte, puede que así sea, pero el diagnóstico ha de ser forzosamente más complejo: la recuperación de la autoridad central y el sistema creado de sustracción y distribución del excedente no debe satisfacer a todo el mundo, y mucho menos a la pequeña nobleza que reclama poder y riqueza (señoríos dentro de los señoríos). Quizá es por ello que, paralelamente a la creación del Estado feudal, se produce una formidable oleada de violencias feudales, bien reflejadas en las querimoniae conservadas y en las definitiones contenidas en cartularios y archivos eclesiásticos. Esta conflictividad debe ser el marco de fuerza en el que cristalizan las jurisdicciones o reparto tácito de los poderes judiciales.

Del mismo modo que a principios del siglo $\mathrm{xI}$, la actuación de prestigiosos juristas como Ponç Bonfill Marc y las mejores manisfestaciones de la mecánica del pleito tradicional coincidian con las primeras manifestaciones de crisis del sistema judicial tradicional (burlas y desplantes a la justicia, tentativas de sustituir las pruebas habituales por actos de fuerza), ahora, durante la segunda mitad del siglo XII, bajo el impulso del derecho sabio, y la acción de nuevos juristas, la administración de justicia inicia un proceso de recuperación en un contexto, no obstante, de violencias y luchas dentro de la clase dominante. Es como si en los puntos de inflexión, la dinámica jurídicoprocesal y la sociopolítica andaran a distinto ritmo.

145 ¿Habrá que recordar una vez más que en Cataluña se hizo constitución el derecho de los señores a maltratar impunemente a sus campesinos (Cortes de Cervera de 1202)? No sólo en Cataluña, también en Francia en la misma época se adoptaron parecidos mecanismos de resolución de conflictos, según muestran los estudios de WHITE, Stephen D., «Pactum ... Legem Vincit et Amor Judicium. The settlement of disputes by compromise in Eleventh-Century Western France», American Journal of Legal History, 22, 1978, págs. 281-308, y GEARY, Patrick J., "Vivre en conflit dans une France sans état: typologie des mécanismes de règlement des conflits (1050-1200)", Annales ESC, 5, 1986, págs. 1.107 1.133.

146 Bastardas, Joan, Usatges de Barcelona. El Codi a mitjan segle XII, Barcelona, 1984.

Hispania, LVII/3, nùm. 197 (1997) 1009-1048 
Los indicios de este cambio aparecen en el CSCV cuando vemos a Ramon Berenguer IV presidiendo un juicio, después de cien años de desaparición de la justicia condal en este cartulario, y cuando observamos a prelados, juristas profesionales, bailes y vegueres, ya a finales del siglo XII, presidiendo los tribunales en nombre del conde-rey. Algo parecido sucede en el CC cuando observamos a Ramon Berenguer IV terciar en la polémica entre la sede gerundense y la nobleza local por la posesión de bienes y derechos de las iglesias a favor de la primera. La recuperación de autoridad que esta decisión entraña debe ser la premisa que permite plasmar en actos la recepción del derecho sabio, perceptible a finales de siglo con la aparición de un juez como Berenguer de Calonge que interviene en diversas controversias, juicios y actos jurídicos de la sede ${ }^{147}$. De estos merece especial atención la causa (negotium) entre el obispo y el noble Guilabert de Cruilles, que dirimieron el mencionado juez Berenguer de Calonge y Gaufred, chantre de la catedral, en $1180 \circ 1181{ }^{148}$. El proceso puede ser tomado como ejemplo de la nueva justicia cuando se aplica a litigios entre poderosos.

Ante aquellos jueces se presentó Guilabert de Cruïles para reclamar al obispo la castellanía de la Bisbal que habían tenido sus antepasados, alegación que la parte episcopal contradijo. Los jueces pidieron entonces pruebas escritas y testigos. Guilabert presentó el testamento de su abuelo, en el que constaba que éste había dejado el castillo a su hijo, y dos testigos, que declararon haber visto $\mathrm{u}$ oído como los Cruilles antepasados del actual habían poseído la castellanía, pero discreparon sobre la época en que había cesado esta posesión. Un testigo dijo que desde la época del obispado de Berenguer Dalmau (1114-46), es decir, desde hacía más de cincuenta años, y otro que habían transcurrido cien años. Respecto del testamento, la parte episcopal respondio que carecía de valor como prueba contraria porque los obispos anteriores ni intervinieron en él ni lo suscribieron. En cuanto a las declaraciones de los testigos, la parte episcopal tampoco se consideraba perjudicada porque discrepaban entre sí totalmente en el tiempo, no probaban como los Cruilles habían adquirido y perdido la castellanía ni la legitimidad de esta posesión. La parte episcopal añadía incluso que, aún en el caso de que todo fuera cierto, tampoco resultaría perjudicada por la declaración testifical, y ello a causa de con el paso de los años (cincuenta o cien) los derechos de los Cruilles habrían prescrito y fundamentado, en cambio, los de la sede por longueva posesión (propter legitimam prescriptionem et longevam posessionem).

Contra ello Guilabert de Cruilles argumentó que la parte episcopal no podía oponer legítima prescripción porque ésta muchas veces había sido interrumpida. Y para confirmarlo explicó que hizo un pacto con el obispo Berenguer de Llers (1147-59) puesto que por este litigio encerró a su baile de la Bisbal; que, con el consejo de hombres buenos, llegó a una transacción duradera con el obispo Guillem de Peratallada (1160-68), y que a su muerte llegó

147 CC $343,351,360$ y 362.

$348 \mathrm{CC} 343$. 
a un acuerdo con el obispo Guillem de Monells (1168-78) por el que seguiría la via judicial (intrare in causa). Presentó para ello testigos, pero los jueces no quisieron admitirlos. De este modo, insistió, la prescripción se había interrumpido. La parte episcopal respondió diciendo que a causa de la detención del baile no se había interrumpido la prescripción, puesto que simples querimoniae presentadas fuera de los tribunales no sirven para interrumpir una prescripción; lo pertinente es que se interrumpa o naturalmente o civilmente. Sobre la transacción hecha con el obispo Guillem de Peratallada dijo que no perjudicaba la causa de la sede puesto que no fue hecha en derecho (in iure). Guilabert de Cruilles crefa, dijo, que se había hecho en derecho, puesto que se hizo en presencia de muchos canónigos. Sobre la apertura de un proceso (De litis contestatione) con el obispo Guillem de Monells, la parte episcopal dijo que tampoco afectaba a la cuestión de la prescripción porque los supuestos derechos entonces ya habian prescrito y porque los testigos no fueron admitidos por el tribunal. Y no fue el obispo sino los jueces quienes no quisieron admitirlos porque no se presentaron todos y porque decían que la costumbre de esta tierra (consuetudinem huius terre) era que fueran admitidos todos a la vez. Y así, a lo argumentos que Guilabert de Cruilles reiteradamente formulaba en su reclamación (petitio), la parte del obispo respondía con otros. Finalmente, escuchadas y comprendidas las razones y alegaciones de cada parte, los jueces, con el consejo de Enrique, cardenal de Albano y legado de la sede apostólica, absolvieron a la sede gerundense de la demanda formulada contra ella.

Esta causa y proceso sirve para mostrar que a finales del siglo XII se están produciendo cambios importantes en los mecanismos de resolución de conflictos entre poderosos, al menos entre la nobleza y la Iglesia ${ }^{149}$, y que los cambios tienen mucho que ver con la evolución del derecho en Cataluña. Los acuerdos negociados al margen de los tribunales (convenientiae, transactiones), tan numerosos en ambos cartularios, desde ahora pierden terreno en provecho del derecho sabio de tradición romana y la justicia profesional.

El pleito examinado es claramente una causa de naturaleza feudal, para cuyo desarrollo y desenlace hay que considerar tanto la tradición jurídica hispanogoda, como las costumbres feudales, el código juridico de los Usatges y el derecho romano renaciente en los capítulos catedralicios ${ }^{150}$. La Bisbal era de dominio episcopal desde siglos atrás, pero, como sucedía en otras villas de la sede, la nobleza local ejercía poderes y participaba del reparto del excedente en ella. Desde la primera mitad del siglo xir o desde ante hubo por ello conflictos entre los obispos y los Cruilles, quienes tuvieron que entregar a la

149 Para avalar esta afirmación hay muchas pruebas documentales, algunas incluso anteriores al juicio examinado.

150 Los Usatges de Barcelona se promulgaron precisamente porque en el articulado de la Lex Visigothorum no se contemplaban los conflictos feudales entre señores y vasallos. Después de su promulgación, la Lex pasó a ser ley supletoria, según dice el Usatge Iudicia Curiae (Us. 81 del texto oficial). 
sede las tascas y pleitos que percibían ${ }^{15 i}$, y quizá también la castellanía, que después intentaron recuperar con negociaciones y transacciones. En 1180, el obispo encomendó la guarda del castillo de la Bisbal a un caballero, lo que debió exasperar a Guilabert de Crü̈lles, que reclamó la castellanía ante el tribunal del obispo, formado por un juez profesional y un canónigo, que pidieron pruebas documentales y testigos. Se cumplían de este modo las formalidades de rigor. Pero lo revelador es el debate.

La parte episcopal rechazó la prueba del testamento del abuelo Cruilles con el argumento de derecho feudal de que no había sido refrendado por los obispos de Gerona, señores del lugar. Después alego, de acuerdo con la Lex y los Usatges, la prescripción de treinta años y la consiguiente longueva posesión de la castellanía por parte de la sede para negar a Guilabert de Cruïlles cualquier derecho sobre la misma ${ }^{152}$. Después, se arropó en el derecho romano para cargar contra las prácticas feudales tradicionales. Así, el procurador del obispo sostuvo que las simples quejas (querimoniae) presentadas fuera de juicio no interrumpían la prescripción legal de treinta años, y añadió que lo pertinente es que la interrupción se produzca por razones de derecho natural y civil, una distinción, por cierto, netamente romana. En la misma línea, pero de manera más arriesgada, el procurador afirmó que un acuerdo o transacción particular, entre el obispo Guillem de Peralada y Guilabert, no tenía fuerza legal (non fuit facta in iure), aunque al parecer se hizo ante testigos. En el fondo, creemos entender, se trata de una confrontación directa entre el derecho feudal (en el que se basa Guilabert de Crülles y que, como se sabe, es en gran medida consuetudinario) y el derecho romano y canónico (en el que se basa la parte episcopal y que es derecho escrito). Quizá el argumento formal e implícito del procurador del obispo era que la transacción se había hecho oralmente y no por escrito, pero una gran parte de los pactos feudales debían formularse sólo de palabra, aunque siempre ante testigos, lo cual hasta ahora resultaba suficiente para considerarlos válidos ${ }^{153}$. Asistimos así a una oposición entre el derecho romano y la tradición feudal (incluso la recogida en los Usatges), que implica también un cambio en las formas de solución de conflictos.

Antes, los jueces cedían su lugar a amigables componedores o árbitros. Ahora, afianzados sobre el derecho romano renaciente ${ }^{154} \mathrm{e}$ inspirándose si convenía en los Usatges ${ }^{155}$, siguen un procedimiento regular, escuchan razo-

151 CC 264,281 y 284.

152 Nos referimos al Usatge Omnes cause (Us. 156), que sigue, de hecho, a la prescripción trentenaria de la $\operatorname{Lex}(\mathrm{X}, 2,4)$.

${ }_{153}$ De hecho, el Usatge Comunie (Us. 70) asi lo indica.

154 El mismo derecho o influencia jurídica, que permitió al conde de Barcelona promulgar los Usatges, y en particular el Usatge Pinceps namque (Us.68) por el que se atribuye el derecho a reclamar el servicio militar a todos los hombres de su tierra.

155 Tenernos la impresión de que el procurador del obispo se sirve de argumentos extraidos de la Lex, el derecho romano y los Usatges, según mejor le conviene.

Hispania, LVIU/3, núm. 197 (1997) 1009-1048 
nes fundamentadas en códigos escritos y sentencian ${ }^{156}$. La terminología misma del documento revela los cambios que se operaban en derecho procesal y su inspiración: para referirse a la causa que años antes había enfrentado a Guilabert de Crülles con el obispo Guillem de Monells, y negar que esta causa hubiera interrumpido la prescripción, el escriba anota De litis contestatione, expresión anteriormente inusual y con la ahora que se designa una de las fases del proceso romano-canónico ${ }^{15 ?}$.

Como se ve, el derecho sobre el que se fundamentan las relaciones humanas en los condados catalanes era una pluralidad que daba un cierto margen a las interpretaciones. En el cabían incluso las tradiciones locales. Precisamente el litigio iniciado entre Guilabert de Cruilles y Guillem de Monells fue abortado por los propios jueces al no admitir los testigos aportados por aquel en base a una costumbre local según la cual los testigos debían admitirse en bloque (ut omnes insimul admitterentur), y no procedía la declaración cuando faltaba algún testigo: iudices noluerunt eos admittere quia non omnes ibi aderant.

En este contexto jurídico de afirmación del derecho sabio, que incorpora, si conviene, normas de los Usatges y de la Lex, es congruente que el fallo del tribunal, favorable a la sede, fuera consultado al propio cardenal legado, llegado de Italia, que debía ser un experto en derecho romano-canónico.

\section{LA JUSTICLA EN EL ESTADO FEUDAL}

Al final de la evolución creemos regresar a los orígenes. Con ello queremos decir que la justicia, al menos en las querellas entre poderosos y sobre todo cuando se trataba de conflictos entre la nobleza y la Iglesia, parece volver a manos del clero (los hombres cultos de la época) ${ }^{158}$, lo cual justificaría una vez más los recelos de los guerreros respecto de la institución eclesiástica ${ }^{159}$. Esto, unido a las crisis de autoridad que experimentó la monarquía durante el siglo XIII, explica que este tipo de litigios, aunque se dirimieran a partir de ahora ante tribunales de jueces profesionales, rebrotaran a menudo y obligaran todavía a recurrir a transacciones y pactos a la usanza tradicional ${ }^{160}$. Gui-

156 Las formas de compromiso, como mecanismos de resolución de conflictos, predominantes en los siglos XI y Xli, fueron sustituidas por decisiones fijadas a través de la aplicación de reglas de derecho en la Francia del siglo XIII, según CHEYETrE, F., «Suum Cuique Tribuere», French Historical Studies, VI, 1970, págs. 287-299.

157 Agradecemos esta información y otras orientaciones sobre la interpretación de este documento al profesor Tomás Montagut.

158 Dicho esto de modo general y en comparación con el periodo anterior en que los consejeros, amigables componedores y árbitros generalmente eran clérigos y laicos mezclados, quizá con predominio de los segundos.

159 Véase supra núm. 143.

160 Significativamente, entre los documentos del CC de los siglos Xill y xuv hay numerosas escrituras por las que miembros de la nobleza gerundense se reconocen feudatarios del obispo por los diezmos de las parroquias. $¿ Q$ Qué quiere decir ello sino que los conflictos del siglo XII por los 
labert de Cruîlles, por ejemplo, cometió después de 1180-81 diversas malefactas en el dominio episcopal por las que fue excomulgado, lo que le indujo en 1226 a negociar una transacción con el obispo ${ }^{161}$.

Pero apuntar límites en la eficacia de los tribunales de justicia no significa menospreciar los cambios observados que la documentación posterior confirma. Entre los documentos del CSCV del siglo XII encontramos todavía una decena de definitiones (no confundibles con simples ventas), muy pocas para lo que estábamos acostumbrados. Son, como de costumbre, el resultado de un arbitraje o más bien de una amigable composición (ad finem et concordiam et ad bonam pacem), con concesiones por ambas partes ${ }^{162}$. Más interesante es destacar la presencia de veintitres actas de juicios (incluimos los arbitrajes) 163 , ocho de los cuales fueron llevados ante el tribunal del veguer del rey en Barcelona y en el Penedès ${ }^{164}$. Al parecer, en cuatro de estas causas el veguer llevó personalmente el juicio ${ }^{165}$, aunque más frecuentemente delegó esta función en jueces expertos, constituidos al efecto ${ }^{166}$. En un caso actuó un juez por delegación del juez ordinario del rey en el Penedès, oficial que estaba a las órdenes del veguer, quien encabeza las signaturas del documento ${ }^{167}$. Otra causa fue dirimida por el tenens locum domini regis en Piera, quien, a la vista de que el oponente del monasterio se negaba a aceptar el proceso (noluit firmare directum, nec pignora reiterare, nec ius facere, nec causam producere), ordenó al baile del rey que entregara a Sant Cugat el bien en disputa ${ }^{168}$. En comparación con la situación anterior a 1150, la justicia real, servida por oficiales (vegueres y bailes) y expertos (jueces ordinarios o constituidos al efecto), se afirma. El propio monarca estimula el recurso a su jurisdicción cuando en 1225 concede al monasterio el privilegio de no pagar los costes de la justicia por las causas encomendadas a sus vegueres de Barcelona, el Vallès $y$ el Penedès ${ }^{169}$.

Al margen de la jurisdicción real, se resolvieron, no obtante, algo más de la mitad de los pleitos. Algunos lo fueron por jueces nombrados directamente por el abad o sus colaboradores en virtud de sus poderes jurisdiccionales ${ }^{170}$.

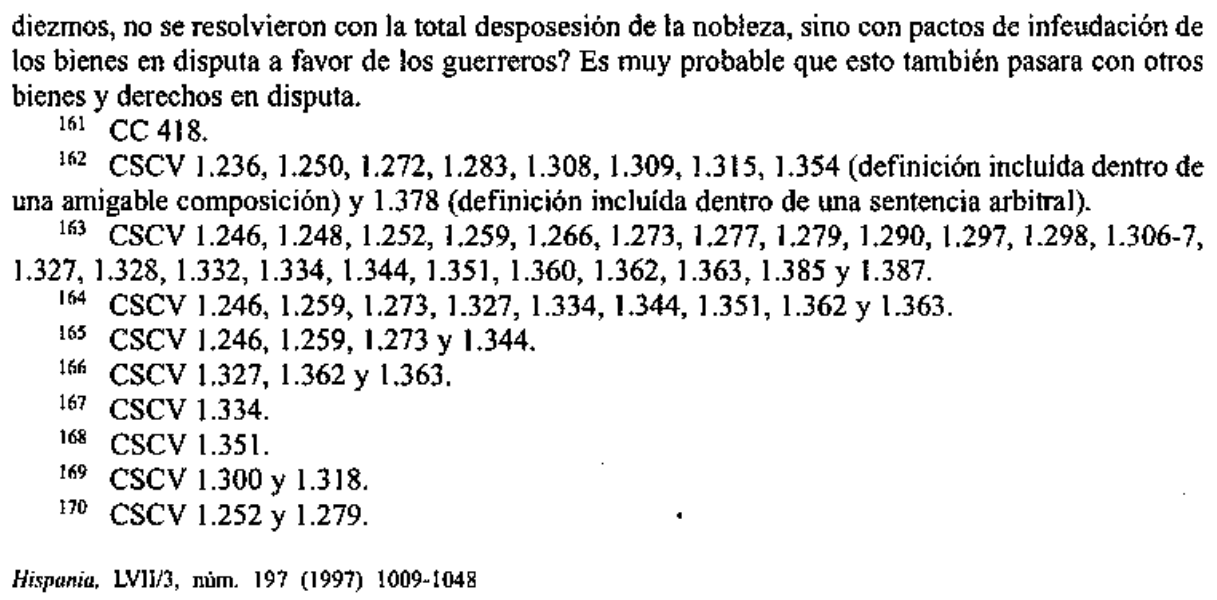


Se trata de causas que conciernen a bienes y hombres del dominio monacal. Otros, más numerosos, fueron dirimidos por árbitros o jueces (causae cognitores) escogidos por las partes, después de largas disputas y del compromiso escrito de aceptar el veredicto o pagar una sanción en caso contrario (Post multa placita et contenciones... placuit eis stare laudi et arbitrio... promitentes firmiter per stipulacionem sub pena $C$ aureorum eorundem laudi et arbitrio parere), o directamente designados por la autoridad monacal (unde nos...assumpti iudices a iam dicto camerario $s$. Cucuphatis in hac causa) ${ }^{171}$. Algunos conflictos fueron disputas entre Sant Cugat y otra institución eclesiástica (Santes Creus, sede de Tortosa) resueltos en arbitraje por una instancia eclesiástica superior ${ }^{172}$.

Hay, por último, algunos pleitos resueltos por amigable composición, a la que se llegó mediante laudo o consejo de amigos ${ }^{173}$, y sentencias pronunciadas en apelación por la jurisdicción real y la eclesiástica ${ }^{174}$.

Como de costumbre, el monasterio pleitea por la posesión de mansos, tierras, rentas, monopolios, castillos y bailías, muchas veces con miembros de la nobleza local que someten a cargas indebidas a los tenentes de Sant Cugat. La novedad es que en las disputas aparecen derechos enfitéuticos (fadiga y laudemio) sobre los que la monarquía justamente hubo de legislar en esta época ${ }^{175}$, y disputas por la posesión de hombres propios ${ }^{176}$.

En resumen, llama la atención la fuerte presencia de la justicia real, sólidamente organizada, y que los procesos judiciales llevados al margen de la jurisdicción del rey, por jueces señoriales o escogidos por las partes, casi siempre eclesiásticos, se desarrollen con pautas muy regulares, una mecánica compleja y un gran respeto a las formalidades y a la norma escrita. Todo ello por referencia al período anterior. El resultado es un predominio en la documentación de actas o resúmenes extensos de juicios en los que los tribunales dan fe de su proceder. La impresión, al final, es que la fuerza juega su papel (afianzamiento del poder monárquico como clave del edificio jurídico), pero también que se abre paso entre los hombres de cultura y de poder lo que podríamos llamar una tendencia a confiar en la razón jurídica objetivada en el derecho escrito.

El examen de los documentos del siglo XIII del CC lo corrobora, y aporta nuevas claves para comprenderlo. En primer lugar hay que entender que el poder episcopal es superior al abacial, es decir, tiene más medios para imponerse a los poderosos, to que hace innecesario e incluso arriesgado, desde el punto de yista del obispo (si quiere preservar su independencia), recurrir a la justicia real. De entre estos medios, la excomunión fue ampliamente utilizada:

$171 \mathrm{CSCV} 1.248,1.266,1.277,1.279,1.290,1.297,1.298,1.360$ y 1.387

172 CSCV $1.328,1.332$ y 1.385.

173 CSCV $1.260,1.325$ y 1.354.

174 CSCV $1.328,1.332$ y 1.334 ,

175 BrocA, Guillermo M.", Historia del derecho de Cataluña, especialmente del civil, Barcelona, 1918, págs. 241-244.

176 CSCV $1.279,1.297$ y 1.327 .

Hispania, LVII/3, núm. 197 (1997) 1009-1048 
contra vasallos díscolos y rapaces, como Guilabert de Cruïles (1226), contra vecinos peligrosos y hostiles, como el conde de Ampurias (1200 y 1225), y contra el propio monarca como Pedro el Católico (1210), que practicaba la pirateria señorial ${ }^{177}$. Debió ser, en parte, por la excomunión o su amenaza que muchos señores, que con sus mesnadas se lanzaban al saqueo de bienes de la Iglesia de Gerona, prometieron someterse a la justicia del obispo o del juez designado por éste y cumplir las sanciones que se les impusieran o definieron los abusos que cometían ${ }^{178}$. Asi la excomunión, finalmente refrendada y reforzada por disposiciones reales ${ }^{179}$, debió contribuir a afianzar la autoridad del obispo y su justicia. Pero esta justicia, ejercida por jueces y clérigos expertos en derecho romano, cuyas leyes aplicaban metódicamente, pudo por si misma ganar prestigio y posiciones como forma racional de solución de conflictos. Esto ayuda a comprender el arbitraje ejercido por canónigos ${ }^{180} \mathrm{e}$ incluso por el propio obispo gerundense que, en un caso de apelación de una sentencia dictada por uno de sus oficiales, no dudó en actuar como amigable componedor entre las partes ${ }^{181}$. El principio de independencia de la justicia, basado en la fuerza de la ley y la profesionalidad de los juristas, también debe empezar entonces a abrirse camino. No de otro modo se comprende que la palabra juez, que en épocas pasadas se aplicaba a veces un tanto indiscriminadamente a todos los que intervenian en la resolución de conflictos, ahora se reserve para jueces nombrados por la autoridad competente (quien tiene poderes jurisdiccionales) para juzgar causas concretas o investidos de tal facultad sin limitación de causas, como jueces ordinarios. Precisamente a un juez ordinario acudieron los campesinos de Ullà (secundados por el obispo) y los de Canet de Verges (secundados por el conde de Ampurias) cuando quisieron dirimir diferencias sobre términos parroquiales y aprovechamiento de aguas ${ }^{182}$. En cambio, a los que no eran jueces profesionales, nombrados por la potestad, sino árbitros elegidos por las partes sutilmente se les denomina "conocedores de la causa" (cognitores eius cause).

Las citas y ejemplos podrían alargarse casi indefinidamente. Bastaría con incorporar nuevas fuentes. Pero con ello quizá no haríamos más que ilustrar lo sabido, sin modificar las conclusiones alcanzadas. Nos limitaremos, pues, a incorporar un último análisis de caso, que cerrará nuestro estudio y corroborará la idea que defendemos del gran cambio experimentado por la justicia y la sociedad desde la segunda mitad del siglo XII.

En 1245, comparecen ante Arnau de Miana, juez nombrado por Guillem de Cornellà, paborde de la sede gerundense, este paborde y el campesino del manso Canelles (primero Berenguer y después su hijo Pere), que es baile y

\footnotetext{
177 CC $378,399,413$ y 418 .

178 CC $378,393,397,399,413,416,418$ y 452 .

$179 \mathrm{CC} 400$

180 Tandem in Marchesium Gerundensem canonicum compromiserunt et in eius arbitrio sponte se subiecerunt (CC 409).

181 CC 458.

182 CC 496.

Hisparia, LVII/3, núm. 197 (1997) 1009-1048
} 
hombre propio de la Iglesia. El paborde presenta tres denuncias o reclamaciones (el escribano anota al inicio de cada una Guilielmus de Corneliano primum o secundum o tercium libellum obtulit in hunc modum) y la parte contraria responde a cada acusación con sus argumentos (el escribano anota Et Berengarius litem contestando respondit libello) desarrollándose con razón de la primera denuncia varios turnos de réplica y contraréplica. La primera acusacion, reveladora del avance de la servidumbre, es por el hecho de que una hija del campesino ha dejado el manso para casarse con un joven de otra jurisdicción. El paborde quiere o bien su regreso o el pago de la remensa. La segunda reclamación concierne a la anulación, que el paborde solicita (beneficium restitucionis), de un acuerdo (instrumentum transactionis seu compositionis) anterior favorable al baile y perjudicial para la sede, que con él perdía rentas importantes. Y la tercera denuncia concierne al poblamiento del manso Vilarrasa, que el paborde entiende debe ser poblado por hombres propios de la sede o definido, contra el proceder de su oponente.

$\mathrm{Si}$ interpretamos el documento en un sentido general, diremos que las demandas están orientadas a acentuar el control sobre los hombres, tierras y excedente del dominio episcopal, comprometido por la independencia alcanzada por los pequeños administradores locales. El proceso, metódicamente ordenado de acuerdo con el modelo del proceso romano canónico, termina, después de las proposiciones de cada parte y del examen de las escrituras presentadas, con la sentencia o sentencias dictadas por el juez, que también se presentan ordenadamente y con la nueva terminología: In primo libello ... condemnavit ... Item absolvit ... in secundo libello ... Item in tercio libello sententiando diffinitive adjudicavit ${ }^{183}$. La palabra libellus, utilizada aquí tan sistemáticamente en el sentido de demanda o acusación, no la habíamos encontrado en la documentación anterior (anterior al menos a 1150), y creemos no existe con este sentido en la Lex. Pero en general es todo el documento, con su sistemática de acusaciones, réplicas, contrarréplicas y sentencias ordenadas y sutilmente diferenciadas, lo que evidencia el cambio. Comparado este juicio, y otros examinados más arriba, con las formas de resolución de conflictos de la segunda mitad del siglo xI y primera mitad del XII el giro es enorme. Incluso socialmente: los campesinos (aunque fueran bailes) no parece que anteriormente fueran tratados por la justicia con la atención con que lo fue este campesino del manso Canelles, que, por cierto, ganó la segunda demanda: Item absolvit Petrum de Canellis a restitucione contra se intentata in secundo libello, et in eadem Guilielmum de Corniliano condempnavit. Claro que esto sucede dentro de la jurisdicción eclesiástica y, por lo que deducíamos de los documentos del CSCV, también en la real. Habría que ver lo que sucede en las jurisdicciones de la nobleza, pero averiguarlo es ya el tema de otro estudio.

Si uno piensa globalmente la evolución examinada no puede asirse a la idea de progreso. Tampoco rechazarla. Los eslabones del proceso justifican la

$183 \mathrm{CC} 464$. 
ambivalencia. 1/ Partíamos de una justicia, con códigos escritos, pruebas objetivas y procesos regulados, que se llamaba a sí misma justicia pública (jueces públicos, audiencias públicas), pero, por su inserción en un tejido institucional regido por los poderosos y por la Iglesia, creíamos ajustado hablar de justicia de clase ${ }^{184} \mathrm{y}$ de casta. Era, además, y esto hay que subrayarlo, una justicia que aplicaba un derecho segregacionista, que los cambios sociales tornaban obsoleto. 2/ Hemos visto después como este derecho y esta justicia entran en crisis desbordados por los cambios sociales y el empuje de las relaciones de fuerza en el seno de la sociedad. Los poderosos prefieren entonces resolver sus conflictos al margen de los tribunales en el campo de batalla y en la mesa (o asamblea) de negociaciones. Es como si estuvieran buscando sus límites. El pacto reemplaza a la justicia en las relaciones entre los grandes. En todo caso, la nueva justicia, cuando se aplica a los débiles parece más una justicia personal (basada en la voluntad del poderoso de turno) que institucional o de clase, en la medida en que la clase feudal naciente todavía entonces no había institucionalizado su hegemonía en una forma política estatal. 3/ Finalmente se reestructura el proceso como mecanismo regular e institucional de resolución de conflictos y ajuste de relaciones sociales y comportamientos. Parece haberse superado una fase en que la voluntad individual de los poderosos no reconocía más límites que la fuerza de los demás. Pero no se puede olvidar que en el proceso una gran parte de la sociedad campesina ha quedado aprisionada en las redes de la servidumbre, y sometida a tribunales señoriales, que juzgan de acuerdo con costumbres locales (del señorío), aunque no ignoran totalmente las aportaciones del derecho sabio.

Decir que a partir de estas premisas, el derecho (en relación dialéctica con el tejido social y la forma política), y la justicia como campo específico, con todas las dificultades, lentitudes y desvíos imaginables, avanzó durante la Baja Edad Media y la Edad Moderna hacia la construcción de una sociedad donde la arbitrariedad fuera limitada, me parece que no es ninguna ingenuidad. En todo caso, no pretendemos con ello ir más lejos de lo escrito por E.P. Thompson, con referencia a la Edad Moderna, cuando explica que "los obstáculos sobre el poder impuestos por la ley parecen ... un legado tan substan. cial como cualquier otro transmitido por las luchas del siglo xvII al xVIII, y un auténtico e importante logro cultural" 185.

194 Al menos en la medida en que el Estado tardoantiguo y altomedieval (del que la administración de justicia formaba parte) pudiera ser la expresión política de la hegemonia de la clase dominante.

185 Citado por KAYE, Harvey J., Los historiadores marxistas británicos, Zaragoza, 1989, pág. 186, quien affade otra cita de Thompson que nos parece oportuno reproducir: «ningún pensador socialista serio puede suponer que ningún precepto legal es un profundo bien hurnano».

Hispania, LVII/3, tứm. 197 (1997) 1009-1048 